NBER WORKING PAPER SERIES

TRADE LIBERALIZATION, POVERTY AND
INEQUALITY: EVIDENCE FROM INDIAN DISTRICTS

Petia Topalova

Working Paper 11614

http://www.nber.org/papers/w11614

NATIONAL BUREAU OF ECONOMIC RESEARCH

1050 Massachusetts Avenue

Cambridge, MA 02138

September 2005

I am indebted to Abhijit Banerjee, Esther Duflo, Sendhil Mullainathan and Nina Pavcnik. This paper also benefited from discussions with Robin Burgess, Shawn Cole, Eric Edmonds, Ivan Fernandez-Val, Rema Hanna, Ann Harrison, Andrei Levchencko, the participants in the development lunches at MIT and the NBER Conference on Globalization and Poverty. This paper is forthcoming in the NBER book "Globalization and Poverty," edited by Ann Harrison, to be published by the University of Chicago Press. Department of Economics, Yale University; petia@mit.edu. The views expressed herein are those of the author(s) and do not necessarily reflect the views of the National Bureau of Economic Research.

(C2005 by Petia Topalova. All rights reserved. Short sections of text, not to exceed two paragraphs, may be quoted without explicit permission provided that full credit, including (C) notice, is given to the source. 
Trade Liberalization, Poverty, and Inequality: Evidence from Indian Districts

Petia Topalova

NBER Working Paper No. 11614

September 2005

JEL No. F1

\begin{abstract}
Although it is commonly believed that trade liberalization results in higher GDP, little is known about its effects on poverty and inequality. This paper uses the sharp trade liberalization in India in 1991, spurred to a large extent by external factors, to measure the causal impact of trade liberalization on poverty and inequality in districts in India. Variation in pre-liberalization industrial composition across districts in India and the variation in the degree of liberalization across industries allow for a difference-in-difference approach, establishing whether certain areas benefited more from, or bore a disproportionate share of the burden of liberalization. In rural districts where industries more exposed to liberalization were concentrated, poverty incidence and depth decreased by less as a result of trade liberalization, a setback of about 15 percent of India's progress in poverty reduction over the 1990s. The results are robust to pre-reform trends, convergence and time-varying effects of initial district-specific characteristics. Inequality was unaffected in the sample of all Indian states in both urban and rural areas. The findings are related to the extremely limited mobility of factors across regions and industries in India. The findings, consistent with a specific factors model of trade, suggest that to minimize the social costs of inequality, additional policies may be needed to redistribute some of the gains of liberalization from winners to those who do not benefit as much.
\end{abstract}

Petia Topalova

Yale University

Department of Economics

28 Hillhouse Avenue

New Haven, CT 06520

petia@mit.edu 


\title{
Trade Liberalization, Poverty and Inequality: Evidence from Indian Districts
}

\author{
Petia Topalova*†
}

\section{Introduction}

After the Second World War, India, along with other developing countries, chose a strategy of import substitution as a means of industrializing. In the past two decades, however, many countries have begun to favor global economic integration, and in particular trade liberalization, as a development strategy. Although there is a general presumption that trade liberalization results in a higher Gross Domestic Product, much less is known about its effects on income distribution. The distributional impacts of trade are particularly important in developing countries, where income inequality is typically pronounced and there are large vulnerable populations. If economic integration leads to further growth in income inequality and an increase in the number of poor in developing economies, the benefits of liberalization may be realized at a substantial social cost unless additional policies are devised to redistribute some of the gains from the winners to the losers.

Standard economic theory (Hecksher-Ohlin model) predicts that gains to trade should flow to abundant factors, which suggests that in developing countries, unskilled labor would benefit

${ }^{*}$ I am indebted to Abhijit Banerjee, Esther Duflo, Sendhil Mullainathan and Nina Pavcnik. This paper also benefited from discussions with Robin Burgess, Shawn Cole, Eric Edmonds, Ivan Fernandez-Val, Rema Hanna, Ann Harrison, Andrei Levchencko, the participants in the development lunches at MIT and the NBER Conference on Globalization and Poverty. This paper is forthcoming in the NBER book "Globalization and Poverty," edited by Ann Harrison, to be published by the University of Chicago Press. The views expressed herein are those of the author and do not necessarily reflect the views of the National Bureau of Economic Research.

${ }^{\dagger}$ Department of Economics, Yale University; petia@mit.edu. 
most from globalization. The rising skill-premium in the U.S. is often cited in support of standard trade theory. However, recently these sharp predictions have been challenged. ${ }^{1}$ According to the new theories, trade liberalization could reduce the wages of unskilled labor even in a labor abundant country, thereby widening the gap between the rich and the poor. Moreover, even if global economic integration induces faster economic growth in the long run and substantial reductions in poverty, the adjustment might be costly, with the burden falling disproportionately on the poor (Banerjee and Newman, 2004). Due to the ambiguity of the theory, the question of how trade liberalization affects poverty and inequality remains largely an empirical one.

Recent empirical work has attempted to address the question, focusing mostly on the effect of trade liberalization on within country income inequality. Studies using cross-country variation typically find little relationship between trade liberalization and levels or rates of change of inequality. ${ }^{2}$ However, these studies face significant problems: cross-country data may not be comparable, sample sizes are small, and changes in liberalization may be highly correlated with other variables important to income processes. A promising alternative is to use micro evidence from household and industry surveys. Several studies examine the relationship between trade reforms and skill-premia, returns to education, industry-premia, and the size of informal labor markets. However, the findings of these studies are typically based on correlations and may not always be given a causal interpretation. And while there is some evidence on the effect of liberalization on industrial performance and wage inequality, the literature has so far ignored the next logical step: the impact of these performance changes on poverty.

This paper investigates the impact of trade reforms on poverty and inequality in Indian districts. Does trade liberalization affect everyone equally or does it help those who are already relatively well off while leaving the poor behind? How does it affect income distributions within rural and urban areas? And is the effect of liberalization felt equally across regions in India?

India presents a particularly relevant setting to seek the answers to these questions. First, India is the home of one third of the world's poor. ${ }^{3}$ Second, the nature of India's trade

\footnotetext{
${ }^{1}$ See Davis (1996), Feenstra and Hanson (1997), Stiglitz (1970), Cunat and Maffezzoli (2001), Banerjee and Newman (2004), Kremer and Maskin (2003).

${ }^{2}$ See Edwards (1997), Lundberg and Squire (1999), Rama (2003), Dollar and Kraay (2002) and Milanovic (2002).

${ }^{3}$ Based on 2001 World Bank estimates. See http://www.worldbank.org/research/povmonitor/.
} 
liberalization-sudden, comprehensive and largely externally imposed-facilitates a causal interpretation of the findings. India liberalized its international trade as part of a major set of reforms in response to a severe balance of payments crisis in 1991. Extremely restrictive policies were abandoned: the average duty rate declined by more than half and the percentage of goods importable without license or quantitative restriction rose sharply. The lower average tariffs, combined with changes in the tariff structure across industries, provide ample variation to identify the causal effects of trade policy on income processes.

Coincident with these tariff reductions were significant changes in the incidence of poverty and income inequality. To determine whether there is a causal link between liberalization and changes in poverty and inequality, this paper exploits the variation in the timing and degree of liberalization across industries, and the variation in the location of industries in districts throughout India. The interaction between the share of a district's population employed by various industries on the eve of the economic reforms and the reduction in trade barriers in these industries provides a measure of the district's exposure to foreign trade. In a regression framework, this paper establishes whether district poverty and inequality are related to the district-specific trade policy shocks. Because industrial composition is predetermined and trade liberalization was sudden and externally imposed, it is appropriate to causally interpret the correlation between the levels of poverty and inequality and trade exposure. Of course if there were migration across districts in response to changes in factor prices, an analysis comparing districts over time may not give the full extent of the impact of globalization on inequality and poverty in India. However, the analysis still gives a well defined answer to the question of whether inequality and poverty increased more (or less) in districts that were affected more by trade liberalization.

The study finds that trade liberalization led to an increase in poverty and poverty gap in the rural districts where industries more exposed to liberalization were concentrated. The effect is quite substantial. According to the most conservative estimates, compared to a rural district experiencing no change in tariffs, a district experiencing the mean level of tariff changes saw a 2 percent increase in poverty incidence and a 0.6 percent increase in poverty depth. This set back represents about 15 percent of India's progress in poverty reduction over the 1990s.

It is important to note that this exercise does not study the level effect of liberalization on 
poverty in India, but rather the relative impact on areas more or less exposed to liberalization. Thus, while liberalization may have had an overall effect of increasing or lowering the poverty rate and poverty gap, this paper captures the fact that these effects were not equal throughout the country, and certain areas and certain segments of the society benefited less (or suffered more) from liberalization.

The finding of any effect of trade liberalization on regional outcomes is puzzling in the trade theorist's hypothetical world, where factors are mobile both across geographical regions within a country and across industries. Factor reallocation would equate incidence of poverty across regions. In a closely related study, Topalova (2004b) presents evidence that the mobility of factors is extremely limited in India. The geographical inequalities are explained by the lack of relocation: migration is remarkably low, with no signs of an upward trend after the 1991 reforms. Topalova (2004b) further examines the mechanisms through which trade liberalization affected poverty and inequality, establishing that the lack of geographical mobility is combined with a lack of intersectoral mobility. Changes in relative output prices led to changes in relative sector-returns to sector specific factors. As those employed in traded industries were not at the top of the income distribution on the eve of the trade reform, the reduction in income caused some to cross the poverty line or fall even deeper into poverty.

This study is related to several strands of literature. First, it fits into the recent large empirical literature on the effects of trade reforms on wage inequality. This literature has largely dealt with the experience of Latin American countries: Cragg and Epelbaum (1996), Revenga (1996), Hanson and Harrison (1999), Feliciano (2001), Goldberg et al. (2001) and Attanasio et al. (2004). Currie and Harrison (1997) study the effect of trade liberalization in Morocco. These papers typically find small effects of trade on wage inequality of workers in the manufacturing sector. This paper extends this type of analysis, by focusing not only on the effect of trade reforms on relative wages in manufacturing, but by looking at regional outcomes in general, thus capturing how trade effects seeped from the directly affected manufacturing and agricultural workers to the their dependents, as well as people involved in non-traded goods sectors.

This is also one of the first studies to examine the link between trade liberalization and poverty. So far Porto (2004) and Goldberg and Pavcnik (2004) have analyzed the relationship between trade and poverty in the case of Argentina and Colombia respectively. While Porto's 
approach has several advantages: it provides a general equilibrium analysis of the relationship between trade liberalization and poverty, by simultaneously considering the labor market and consumption effects of trade liberalization, his results rely on simulations based on cross-sectional data. Goldberg and Pavcnik (2004), exploiting cross-sectional and time-series variation at the industry level, find little evidence of a link between the Colombian trade reforms and poverty. Yet, as the study focuses on urban areas, and people involved in manufacture, it may be missing the really poor. This paper relates plausibly exogenous changes in trade policy to poverty and inequality, studying both manufacturing and agricultural workers in both urban and rural areas. In addition, by defining the district as the unit of observation, it overcomes important selection and composition effects that studies at the industry level may face. Finally, the paper contributes to the literature on industry wage premia and their relation to trade protection.

The remainder of the paper is organized as follows. Section 2 describes the Indian reforms of 1991 focusing on trade liberalization while Section 3 presents the data used in the analysis. In Section 4 the empirical strategy is explained, and the results follow in Section 5. Section 6 concludes.

\section{The Indian Trade Liberalization}

India's post-independence development strategy was one of national self-sufficiency, and stressed the importance of government regulation of the economy. Cerra et al. (2000) characterized it as "both inward looking and highly interventionist, consisting of import protection, complex indus-

trial licensing requirements, pervasive government intervention in financial intermediation and substantial public ownership of heavy industry." In particular, India's trade regime was amongst the most restrictive in Asia, with high nominal tariffs and non-tariff barriers, including a complex import licensing system, an "actual user" policy that restricted imports by intermediaries, restrictions of certain exports and imports to the public sector ("canalization"), phased manufacturing programs that mandated progressive import substitution, and government purchase preferences for domestic producers.

It was only during the second half of the 1980s, when the focus of India's development strategy gradually shifted toward export led growth, that the process of liberalization began. 
Import and industrial licensing were eased, and tariffs replaced some quantitative restrictions, although even as late as 1989/90 a mere 12 percent of manufactured products could be imported under an open general license; the average tariff was still one of the highest, greater than 90 percent. (Cerra et al., 2000)

However, the gradual liberalization of the late 1980s was accompanied by a rise in macroeconomic imbalances - namely fiscal and balance of payments deficits - which increased India's vulnerability to shocks. The sudden increase in oil prices due to the Gulf War in 1990, the drop in remittances from Indian workers in the Middle East, and the slackened demand of important trading partners exacerbated the situation. Political uncertainty, which peaked in 1990 and 1991 after the poor performance and subsequent fall of a coalition government led by the second largest party (Janata Dal) and the assassination of Rajiv Gandhi, the chairman of the Congress Party, undermined investor confidence. With India's downgraded credit-rating, commercial bank loans were hard to obtain, credit lines were not renewed and capital outflows began to take place.

To deal with its external payments problems, the government of India requested a stand-by arrangement from the International Monetary Fund (IMF) in August 1991. The IMF support was conditional on an adjustment program featuring macroeconomic stabilization and structural reforms. The latter focused on the industrial and import licenses, the financial sector, the tax system, and trade policy. On trade policy, benchmarks for the first review of the Stand-By Arrangement included a reduction in the level and dispersion of tariffs and a removal of a large number of quantitative restrictions (Chopra et al., 1995). Specific policy actions in a number of areas - notably industrial deregulation, trade policy and public enterprise reforms, and some aspects of financial sector reform - also formed the basis for a World Bank Structural Adjustment Loan, as well as sector loans.

The government's export-import policy plan (1992-97) ushered in radical changes to the trade regime by sharply reducing the role of the import and export control system. The share of products subject to quantitative restrictions decreased from 87 percent in 1987/88 to 45 percent in 1994/95. The actual user condition on imports was discontinued. All 26 import licensing lists were eliminated and a "negative" list was established (Hasan et al., 2003). Thus, apart from goods in the negative list, all goods could be freely imported (subject to import tariffs) (Goldar, 
2002). In addition to easing import and export restrictions, tariffs were drastically reduced (Figure 1, Panel A and B). Average tariffs fell from more than 80 percent in 1990 to 37 percent in 1996, and the standard deviation of tariffs dropped by 50 percent during the same period. The structure of protection across industries changed (Figure 1 Panel G). Figure 1 Panel H shows the strikingly linear relationship between the pre-reform tariff levels and the decline in tariffs the industry experienced. This graph reflects the guidelines according to which tariff reform took place, ${ }^{4}$ namely reduction in the general level of tariffs, reduction of the spread or dispersion of tariff rates, simplification of the tariff system and rationalization of tariff rates, along with the abolition of numerous exemptions and concessions. Agricultural products, with the exception of cereals and oil seeds, faced an equally sharp drop in tariffs, though the non-tariff barriers of these products were lifted only in the late 1990s (Figure 1, Panels C-F). There were some differences in the magnitude of tariff changes (and especially NTBs) according to industry use type: i.e. Consumer Durables, Consumer Nondurables, Capital goods, Intermediate and Basic goods (Figure 1, Panel D and F). Indian authorities first liberalized Capital goods, Basic and Intermediates, while Consumer Nondurables and agricultural products were slowly moved from the "negative" list to the list of freely importable goods only in the second half of the 1990s. The Indian Rupee was devalued 20 percent against the dollar in July 1991 and further devalued in February 1992. By 1993, India had adopted a flexible exchange rate regime (Ahluwalia, 1999).

Following the reduction in trade distortions, the ratio of total trade in manufactures to GDP rose from an average of 13 percent in the 1980s to nearly 19 percent of GDP in 1999/00 (Figure 2). Export and import volumes also increased sharply from the early 1990s, outpacing growth in real output (Figure 2). India's imports were significantly more skilled-labor intensive than India's exports and remained so throughout the 1990s, as shown in Figure 3 which plots cumulative export and import shares by skill intensity in 1987, 1991, 1994 and 1997.

India remained committed to further trade liberalization, and since 1997 there have been further adjustments to import tariffs. However, at the time the government announced the export-import policy in the Ninth Plan (1997-2002), the sweeping reforms outlined in the previous plan had been undertaken and pressure for further reforms from external sources had abated.

\footnotetext{
${ }^{4}$ The guidelines were outlined in the Chelliah report of The Tax Reform Commission constituted in 1991.
} 


\section{Data}

The data for this analysis were drawn from three main sources. Household survey data is available from the 1983-84, 1987-88, 1993-94 and 1999-2000 ("thick") rounds of the Indian National Sample Survey (NSS). The NSS provide household level information on expenditure patterns, occupation, industrial affiliation (at the 3 digit NIC level) and various other household and individual characteristics. The surveys usually cover all states in India and collect information on about 75,000 rural and 45,000 urban households. ${ }^{5}$ Using this data, I construct district level measures of poverty (measured as headcount ratio and poverty gap) ${ }^{6}$ and inequality (measured as the standard deviation of the log of per capita expenditure and the logarithmic deviation of per capita expenditure). Following Deaton (2003a, 2003b), I adjust these estimates in two ways. First, I use the poverty lines proposed by Deaton as opposed to the ones used by the Indian Planning Commission, which are based on defective price indices over time, across states and between the urban and rural sector. The poverty lines are available for the 16 bigger states in India and Delhi to which I restrict the analysis. ${ }^{7}$ In addition, the 1999-2000 round is not directly comparable to the 1993-1994 round. The 1999-2000 round introduced a new recall period (7 days) along with the usual 30-day recall questions for the household expenditures on food, pan and tobacco. Due to the way the questionnaire was administered, there are reasons to believe that this methodology leads to an overestimate of the expenditures based on the 30-day recall period, which in turn affects the poverty and inequality estimates. To achieve comparability with earlier rounds, I follow Deaton and impute the correct distribution of total per capita expenditure for each district from the households' expenditures on a subset of goods for which

\footnotetext{
${ }^{5}$ The NSS follows the Indian Census definition of urban and rural areas. To be classified urban, an area needs to meet several criteria regarding size and density of the population, and the share of male working population engaged in non-agricultural pursuits.

${ }^{6}$ These measures are explained in detail in Section 4.2. The head count ratio represents the proportion of the population below the poverty line, while the poverty gap index is the normalized aggregate shortfall of poor people's consumption from the poverty line.

${ }^{7}$ Poverty lines were not available for some of the smaller states and union territories, namely: Arunachal Pradesh, Goa, Daman and Diu, Jammu and Kashmir, Manipur, Meghalaya, Mizoram, Nagaland, Sikkim, Tripura, Andaman and Nicobar Islands, Chandigarh, Pondicherry, Lakshwadweep, Dadra Nagar and Haveli. The results are not sensitive to the inclusion of these states, with poverty lines assumed to be the same as those of the neighboring states.
} 
the new recall period questions were not introduced. The poverty and inequality measures were derived from this "corrected" distribution. Throughout the 1990s there were substantial changes in the administrative division of India, with districts' boundaries changing as new districts were carved out of existing ones. As I compare districts over time, I construct consistent time-series of district identifiers using Census Atlases and other maps of India. These were also used to match the NSS and Census district definitions.

For industrial data, I use the Indian Census of 1991, which reports the industry of employment at the 3-digit National Industrial Classification (NIC) code for each district in India. Because the Census does not distinguish among crops produced by agricultural workers, I use the 43rd round of the NSS to compute agricultural employment district weights. There are about 450 industry codes of which about 190 are traded agricultural, mining or manufacturing industries.

Finally, I use tariffs to measure changes in Indian trade policy. While non-tariff barriers (NTB) have historically played a large role in Indian trade policy, data are not available at a disaggregated enough level to allow the construction of a time-series of NTBs across sectors. ${ }^{8}$ Instead, I construct a database of annual tariff data for 1987-2001 at the six-digit level of the Indian Trade Classification Harmonized System (HS) Code based on data from various publications of the Ministry of Finance. I then match 5,000 product lines to the NIC Codes, using the concordance of Debroy and Santhanam (1993), to calculate average industry-level tariffs. The little data on NTBs available comes from various publication of the Directorate General of Foreign Trade as well as the 1992 study of the Indian Trade Regime by Aksoy (1992).

\section{Empirical Strategy}

The Indian liberalization was externally imposed, comprehensive, and the Indian government had to meet strict compliance deadlines. The period immediately before the reform, and the five-year plan immediately following, give rise to an excellent natural experiment. India's large

\footnotetext{
${ }^{8}$ In addition, the experience of other developing countries shows that NTB coverage ratios are usually highly correlated with tariffs, thus estimates based on tariffs may capture the combined effect of trade policy changes (Goldberg and Pavcnik, 2004). This relationship seems to hold in the case of India as well, based on the patchy data available.
} 
size and diversity (India was divided into approximately 450 districts in 27 states at the time of the 1991 Census) allows for a cross-region research design. The identification strategy is straightforward: districts whose industries faced larger liberalization shocks are compared to those whose industries remained protected. Gordon Hanson employs a similar strategy in his study of the effect of globalization on labor income in Mexico in this volume.

However, unlike Hanson's, the identification strategy of this paper exploits variation in the "initial" industrial composition across districts in India and the timing of liberalization across industries. I construct a measure of district trade exposure as the average of industry-level tariffs weighted by the workers employed in that industry in 1991 as a share of all registered workers. The variation in industrial composition will generate differential response of the district level trade exposure to the exogenous changes in tariffs. In a regression framework, the baseline specification takes the following form:

$$
y_{d t}=\alpha+\beta \cdot \operatorname{Tariff}_{d t}+\gamma_{t}+\delta_{d}+\varepsilon_{d t}
$$

Where $y_{d t}$ is district level outcome such as measures of poverty and inequality, and Tariff $d t$ is the district exposure to international trade. The coefficient of interest, $\beta$, captures the average effect of trade protection on regional outcomes. The inclusion of district fixed effects $\left(\delta_{d}\right)$ absorbs unobserved district-specific heterogeneity in the determinants of poverty and inequality, while the year dummies $\left(\gamma_{t}\right)$ control for macroeconomic shocks that affect equally all of India.

The above methodology will capture the short to medium-run effect of trade liberalization in a specific district. Note that in the presence of perfect factor mobility across regions, one would expect no effect of liberalization on regional outcomes. If workers can easily migrate in response to adverse price changes, the effect of liberalization captured in $\beta$ would be zero. A further advantage of this identification strategy is that it will uncover the general equilibrium effect of trade liberalization within a geographical unit. Previous studies have focused on the effect of trade opening on manufacturing workers, who, in developing countries, typically represent a small fraction of the population, though often a large share of income. This strategy will capture not only the effect of trade liberalization on manufacturing and agricultural workers, but also on their dependents, and individuals in allied sectors.

It is important to emphasize that this empirical strategy can not tell us anything about the 
first order effect of trade on poverty. First, trade liberalization is likely to have effects common across India, through prices, availability of new goods, faster growth etc. ${ }^{9}$ Second, it would be very difficult to draw a causal lesson using only time variation in trade liberalization and poverty levels, since the Indian economy was subject to numerous other influences over the period studied. This study, based on regional variation, does not reflect these effects, and does not seek to answer questions about overall levels. Instead, it answers the questions of whether all district derived similar benefits (or suffered similar costs) from liberalization, or whether some areas suffered disproportionately. This is an important question for policy makers who might need to devise additional policies to redistribute some of the gains from the winners to those who do not win as much in order to minimize potential social cost of inequality.

The balance of this section addresses two potential complications. First, the process of trade liberalization is explored in detail, including the possibility that liberalization was correlated with other factors that affect regional poverty and inequality. Second, the measures used to quantify poverty and inequality are described, including careful attention to possible problems with the data, and their solution.

\subsection{Endogeneity of Trade Policy}

There are strong theoretical reasons (Grossman and Helpman, 2002) to believe that in the absence of external pressure, trade policy is an endogenous outcome to political and economic processes. As the empirical strategy of this paper exploits the interaction of regional industrial composition and differential degree of liberalization across industries to identify the effect of trade liberalization on poverty and inequality, understanding the source of variation in the tariff levels is of utmost importance. In particular, there are two dimensions that suggest endogeneity of trade policy may be a concern. First, the initial decrease in tariffs might have been just a continuation of a secular trend. The timing of trade reform might have reflected Indian authorities' perception of domestic industries as mature enough to face foreign competition, and labor and credit markets as flexible enough to ease the intersectoral reallocation that would ensue. Second, the cross-sectional variation in levels of protection might be related to economic and political factors. The relatively less efficient industries might have enjoyed higher degree of

\footnotetext{
${ }^{9}$ To a certain extent the effect of cheaper goods should be reflected in the deflators for the poverty lines.
} 
protection; the political strength of labor as well as business is also often cited as a determinant of trade protection. If less productive industries or industries with higher lobbying ability are more concentrated in poorer areas, then one might see a positive correlation between district poverty rates and the district level tariffs. These two concerns are addressed in sequence below.

As already discussed in Section 2, the external crisis of 1991 opened the way for marketoriented reforms in India, such as trade liberalization. The Indian government required IMF support to meet external payments obligations, and was thus compelled to accept the conditions that accompanied the support. "Given several earlier attempts to avoid IMF loans and the associated conditionalities, the large number of members of the new cabinet who had been cabinet members in past government with inward-looking trade policies and the heavy reliance on tariffs as a source of revenues, these reforms came as a surprise." (Hasan et al., 2003). According to a study on the political economy of economic policy in India, "the new policy package was delivered swiftly in order to complete the process of changeover so as not to permit consolidation of any likely opposition to implementation of the new policies. The strategy was to administer a 'shock therapy' to the economy... There was no debate among officials or economists prior to the official adoption... The new economic policy did not originate out of an analysis of the data and information or a well thought out development perspective," (Goyal, 1996). ${ }^{10}$

Varshney (1999) describes the political environment in which the trade reforms were passed. Mass political attention at the time was focused on internal politics (ethnic conflict in particular), and trade reforms pushed through by a weak coalition government apparently escaped general attention, in contrast to the failed reform attempts of the much stronger Congress Party in 1985. As late as 1996, fewer than $20 \%$ of the electorate had any knowledge of the trade reform, while $80 \%$ had opinions on whether India should implement caste-based affirmative action. While some liberalization efforts (for example privatization) were diluted or delayed due to popular opposition, trade liberalization was generally successful. As Bhagwati wrote: "Reform by storm

\footnotetext{
${ }^{10}$ This view is confirmed in a recent interview with Dr. Chelliah, one of the masterminds of the reforms "We didn't have the time to sit down and think exactly what kind of a development model we needed...there was no systematic attempt to see two things; one, how have the benefits of reforms distributed, and two, ultimately what kind of society we want to have, what model of development should we have?", July 5, 2004 http://in.rediff.com/money/2004/jul/05inter.htm
} 
has supplanted the reform by stealth of Mrs. Gandhi's time and the reform with reluctance under Rajiv Gandhi."

There are several reasons why trade policy remained part of elite politics. Trade constitutes a relatively small part of GDP in India. Though tariffs were vastly reduced, consumer goods and agricultural products were initially not liberalized. And though there surely is an important link between mass welfare and trade policy, even when trade is a small share of the national product, these links are subtle and not yet established empirically.

Even if the timing of the sharp drop in average tariffs (Figure 1) appears exogenous, there is significant variation in the tariff changes across industries, which could confound inference. More precisely, it is important to understand whether the changes in tariffs reflected authorities' perceptions on industry's ability to compete internationally, or the lobbying power of the industry. Ideally, this concern could be alleviated by knowledge of the "true" intentions of Indian policymakers or, failing that, through a detailed study of the political economy behind tariff changes in India over the period. In the absence of objective and detailed analyses of such policy changes, the data may be examined for possible confounding relationships.

First, I examine to what extent tariffs moved together. An analysis of the tariff changes of the 5,000 items in the dataset for 1992-96, the Eighth Plan, and for 1997-2001, the Ninth Plan, suggests that movements in tariffs were strikingly uniform until 1997 (Figure 4). During the first 5-year that incorporated the economic reforms of 1991, India had to meet certain externally imposed benchmarks, and the majority of tariff changes across products exhibited similar behavior (either increased, decreased, or remained constant). After 1997, tariff movements were not as uniform. This suggests that policymakers were more selective in setting product tariffs during 1997-2001, and the problem of potential cross-sectional endogenous trade protection is more pronounced.

Second, there is no evidence that policymakers adjusted tariffs according to industry's perceived productivity during the Eighth Plan, i.e. until 1997. In a related study, Topalova (2004a) tests whether current productivity levels predict future tariffs - a relationship one would expect if policymakers were indeed trying to protect less efficient industries. Topalova (2004a) found that the correlation between future tariffs and current productivity, and future tariffs and current productivity growth is indistinguishable from zero for the 1989-96 period. For the period after 
1997 however, future tariff levels seem to be negatively and statistically significantly correlated with current productivity. This evidence and the evidence on uniformity in tariff movements until 1997 suggest it may not be appropriate to use trade policy variation after 1997 . This study thus focuses on the 1987-1997 period.

A third check uses data from the Annual Survey of Industries (ASI) to test for "political protection." Even if the change in industry tariffs appears uncorrelated with the initial productivity of the industry, tariffs may be correlated with politically important characteristics of the firm. Using data from the ASI, (which covers manufacturing and mining sectors), and following the literature on political protection, I regress the change in tariffs between 1987 and 1997 on various industrial characteristics in $1987 .{ }^{11}$ These characteristics include employment size (a larger labor force may lead to more electoral power and more protection), output size, average wage (policy makers may protect industries where relatively low skilled/vulnerable workers are employed), concentration (as measured by the average factory size, this captures the ability of producers to organize political pressure groups to lobby for more protection), and share of skilled workers. The results are presented in Table 1, Panel A. Tariff changes are not correlated with any of the industry characteristics.

Because agricultural workers are not included in the ASI data, but comprise a large share of India's population, I conduct a similar exercise using data from the 1987 NSS. I estimate for all industries the average per capita expenditure, wage, poverty rate and poverty depth at the industry level, and I check whether there is a correlation between these industry characteristics and tariff declines. Results, presented in Table 1, Panel B, show no significant relationship between tariff changes and these measures of workers' wellbeing, once controls for industry use type are included.

A possible explanation for these results can be found in Gang and Pandey (1996). They conducted a careful study of the determinants of protection across manufacturing sectors across three plans, 1979-80, 1984-85 and 1991-92, showing that none of the economic and political factors are important in explaining industry tariff levels in India. ${ }^{12}$ They explain the phenomenon

\footnotetext{
${ }^{11}$ I use 1987 as the pre-reform year since the data on pre-reform poverty and inequality comes from the 43rd round of the NSS which was collected in 1987. The results are robust to using 1988 or 1990 as the "pre" year.

${ }^{12}$ In other developing countries, protection tends to be highest for unskilled, labor-intensive sectors. See Goldberg and Pavcnik (2001), Hanson and Harrison (1999), Currie and Harrison (1997) for evidence from Colombia,
} 
with the hysteresis of policy: trade policy was determined in the Second Five Year Plan and never changed, even as the circumstances and natures of the industries evolved.

The evidence presented here suggests that the differential tariff changes across industries between 1991 and 1997 were as unrelated to the state of the industries as can be reasonably hoped for in a real-world setting.

One big exception to the otherwise haphazard pattern of tariff reductions are two major agricultural crops: cereals and oilseeds. Throughout the period of study, the imports of cereals and oilseeds remained canalized (only government agencies were allowed to import these items) and no change in their tariff rates was observed (the tariff rate for cereals was set at 0 ). Thus, they were de facto non-traded goods. The delay in the liberalization of these major agricultural crops was due to reasons of food security. However, the cultivators of these crops were also among the poorest in India. This brings some additional complications in the analysis, which are discussed at length in the following sections.

\subsection{Measurement and Basic Patterns of Poverty and Inequality}

Measuring poverty and inequality is not a trivial task. For poverty, I use both the "headcount ratio" (HCR) and the poverty gap. The former, which I refer to as the poverty rate, represents the proportion of the population below the poverty line. While the HCR is widely used, it does not capture the extent to which different households fall short of the poverty line, and is highly sensitive to the number of poor households near the poverty line. Thus, I also analyze the poverty gap index, defined as the normalized aggregate shortfall of poor people's consumption from the poverty line. ${ }^{13,14}$ Figure 5 plots the evolution of poverty in India, and indicates a substantial decline over the past two decades.

\footnotetext{
Mexico and Morocco respectively.

${ }^{13}$ Both the headcount ratio and the poverty gap are members of the Foster-Greer-Thorbecke class of poverty measures, defined as $P_{\alpha}=\int_{0}^{z}\left(\frac{z-y}{z}\right)^{\alpha} f(y) d y$, where $\mathrm{z}$ is the poverty line and incomes are distributed according to the density function $\mathrm{f}(y)$. The headcount ratio is calculated by setting $\alpha$ to be 0 , and the poverty gap by setting $\alpha$ to be 1 .
}

\footnotetext{
${ }^{14}$ Since the survey design changed for the 1999-2000 round of the NSS, in order to obrain internally consistent measurement of poverty and inequality, the per capita expenditure data was adjusted at the district level, following Deaton (2003).
} 
I chose two measures of inequality, the standard deviation of log consumption and the mean logarithmic deviation of consumption, ${ }^{15}$ both because they are standard measures, and because similar values are obtained when they are estimated from either the micro data or the estimated distributions. In contrast to poverty's steady decline, inequality follows a more complicated pattern. While it registered a substantial decline between 1987 and 1993, both measures record a break in that trend and a slight increase in inequality after 1993 in rural India. In urban India, after a period of decline, inequality rose between 1993 and 1999.

As mentioned above, the measure of trade policy is the tariff that a district faces, calculated as the 1991 employment weighted average nominal ad-valorem tariff at time t. ${ }^{16}$ Table A1 in the appendix provides summary statistics of the variables included in the analysis at the district level, including a breakdown of the workers across broad industrial categories. In the average rural district about 80 percent of main $^{17}$ workers are involved in agriculture, of whom 87 percent are involved in cultivation of cereals and oilseeds. Mining and manufacturing account for about 6 percent of the workers and the remaining 12 percent are involved in services, trade, transportation, and construction. In urban India agricultural workers represent only 19 percent, of which 73 percent are cultivators of cereals and oilseeds. Manufacturing and mining workers account for another fifth of the urban population and the remaining three fifths comprise workers in services etc.

The district level tariffs are computed as follows:

$$
\operatorname{Tariff}_{d, t}=\frac{\sum_{i} \text { Worker }_{d, i, 1991} * \text { Tariff }_{i, t}}{\text { Total Worker }_{d, 1991}}
$$

Tariff $_{d, t}$ is a "scaled" version of district tariffs. In this measure, workers in non-traded industries

\footnotetext{
${ }^{15}$ The mean deviation of consumption is part of the family of Generalized Entropy coefficients. It is calculated according to the following formula, $I(0)=\int \frac{y}{\mu} \log \left(\frac{\mu}{y}\right) f(y) d y$, where $\mu$ is mean income.

${ }^{16}$ As described in the Data section, the 1991 population and housing census is used to compute employment by industry for each district. The employment data is available for the urban and rural sector separately by industry at the 3 digit (NIC) level for all workers except agricultural workers. To match agricultural workers to the tariff data, I compute district employment weights from the 43rd round of the National Sample Survey (July 1987-June 1988).

${ }^{17}$ The 1991 Indian census divides workers into two categories: "main" and "marginal" workers. Main workers include people who worked for 6 months or more during the year, while marginal workers include those who worked for a shorter period. Unpaid farm and family enterprise workers are supposed to be included in either the main worker or marginal worker category, as appropriate.
} 
are assigned zero tariff for all years. These are workers in services, trade, transportation, construction as well as all workers involved in growing of cereals and oilseeds. The latter assumption is justified by the fact that all product lines of these two industries were canalized (imports were allowed only to the state trading monopoly) as late as $2000 .{ }^{18}$ Furthermore, the tariffs of all product lines under the growing of cereals industry are 0 throughout the entire period of interest.

One concern with the use of Tariff $d, t$ is that it is very sensitive to the share of people involved in non-traded industries, the majority of whom are the cereal and oilseed growers. Since agricultural workers are usually at the bottom of the income distribution, Tariff $d_{d, t}$ is correlated with initial poverty levels. The interpretation of results based on this measure may be unclear if there were (for other reasons) convergence across districts. In particular, poorer districts, which have a large fraction of agricultural workers may experience faster reduction in poverty due to mean-reversion or convergence. These districts may also record a lower drop in tariffs, since initially the Tariff $d, t$ measure is low. Thus, one might find a spurious negative relationship between tariffs and poverty and erroneously conclude that trade liberalization led to a relative increase in poverty at the district level. Alternatively, if workers in non-traded activities are on a different growth path than those in traded industries, Tariff ${ }_{d, t}$ might capture this differential growth, rather than the effect of trade policies. To overcome this shortcoming, I instrument Tariff $d, t$ with $\operatorname{TrTariff}_{d, t}$, defined as

$$
\operatorname{TrTariff}_{d, t}=\frac{\sum_{i} \text { Worker }_{d, i, 1991} * \text { Tariff }_{i, t}}{\sum_{i} \text { Worker }_{d, i, 1991}}
$$

$\operatorname{TrTariff}_{d, t}$, "non-scaled" tariffs, ignores the workers in non-traded industries. It weighs industry tariffs with employment weights that sum to one for the share of people in traded goods in each district. Thus, a district which has 1 percent workers in traded industries and another district where 100 percent of workers are in traded industries will have the same value of TrTariff ${ }_{d, t}$ if, within the traded industries, the industrial composition is the same. Since the variation in TrTariff ${ }_{d, t}$ does not reflect the size of the traded sector within a district, the "non-scaled" tariff would "overstate" the magnitude of any effect trade policy might have. Yet, TrTariff ${ }_{d, t}$ forms a good instrument, as it is strongly correlated with the "scaled" tariffs and overcomes the correlation with district initial poverty that is there by construction in Tariff $d_{d, t}$. Table 2 presents

\footnotetext{
${ }^{18}$ These products also have minimum support prices fixed by the Government of India.
} 
the results from the first stage. Following equation 1, I estimate the following specification:

$$
\operatorname{Tariff}_{d t}=\alpha+\beta \cdot \operatorname{Tr} \operatorname{Tariff}_{d t}+\gamma_{t}+\delta_{d}+\varepsilon_{d t}
$$

with $\gamma_{t}$ and $\delta_{d}$ defined as above. Columns (1) and (3) present the correlation between the scaled and nonscaled tariffs. There is a very strong relationship between the non-scaled and scaled tariffs in both urban and rural India.

Another instrument is suggested by Figure 1, Panel G: tariff changes are linearly related to initial tariffs. One important principle in the tariff changes was to standardize the tariffs (reduce the standard deviation). A natural consequence of this is that the higher the tariff initially, the greater the reduction. Thus, I use pre-reform unscaled tariffs times a post dummy, in addition to the unscaled tariffs, as instruments for tariff reduction, namely:

$$
\operatorname{Tariff}_{d t}=\alpha+\beta \cdot \operatorname{TrTariff}_{d t}+\theta \cdot \text { Post }_{t} * \operatorname{TrTariff}_{d 1987}+\gamma_{t}+\delta_{d}+\varepsilon_{d t}
$$

Table 2 columns (2) and (4) include the interaction of the initial unscaled tariff and a postliberalization dummy. The interaction of the non-scaled tariffs times a post dummy is also strongly correlated with the scaled tariffs and adds explanatory power in all rural subsamples. In the urban sector, the relationship is not as strong.

Data on outcome variables are available for 3 years: 1987, 1993 and 1999, while tariff data are available annually. It is not known how soon national policy changes affect regional outcomes, though probably there is some lag. If the 1993 outcomes were matched to the 1991 tariffs, 1993 would count as a "pre" year, while if they were matched to the 1992 tariffs, it would be a post year. To avoid this problem, 1993 is omitted from the analysis. I use the earliest available data, 1987, for the "pre" tariff measure, and the 1997 data as the "post" measure.

\section{Results}

I estimate four versions of equation 1: the OLS relationship using Tariff ${ }_{d, t}$; a reduced form using $\operatorname{TrTariff}_{d, t}$; instrumenting for Tariff ${ }_{d, t}$ using $\operatorname{TrTariff}_{d, t}$; and finally instrumenting for Tariff ${ }_{d, t}$

with both $\operatorname{TrTariff} d, t$ and with $\operatorname{TrTariff}_{d, 1987} *$ Post $_{t}$, where Post $t$ is a dummy equal to 1 in year 1999. Since the dependent variable is an estimate, I weight the observations by the square root 
of the average number of households in a district across rounds. Year dummies are included to account for macroeconomic shocks and time trends that affect outcomes equally across India, while district fixed effects absorb district-specific time-invariant heterogeneity. Outcomes of districts within a state might be correlated, since industrial composition may be correlated within a state, thus I cluster the standard errors at the state year level. The results for the four outcomes of interest are presented in Table 3 Section I for rural India and Section II for urban India. Each panel gives the results for a different dependent variable. Columns (1) and (5) give the OLS relationship, columns (2) and (6) the reduced form, and columns (3), (4), (7) and (8), the IV results. In column (4) and (8), I use both the unscaled tariffs and the pre-reform unscaled tariffs times a post reform dummy as an instrument.

In rural India, for both measures of poverty, there is a strong statistically significant negative relationship between district level tariffs and poverty. The decline in tariffs as a result of the sharp trade liberalization appears to have led to a relative increase in the poverty rate and poverty gap in districts whose exposure to liberalization was more intense. The average district experienced 5.5 percentage point reduction in the "scaled" district tariffs. The point estimates of the various specifications are similar, and suggest that this 5.5 percentage point drop would lead to an increase in the poverty rate of 3.2 to 4.6 percentage points, and a 1.1 to 1.8 percentage point increase in the poverty gap. Given that poverty rate in the average district decreased by 12.7 percentage points and that poverty gap decreased by 4 percentage points during the entire decade, the effects of exposure to liberalization are rather large. Surprisingly, there is no statistically significant relationship between trade exposure and poverty in urban India. Though the point estimates are still negative, the magnitude of the coefficients is much smaller than in rural India. There is no statistically significant relationship between trade liberalization and either measure of inequality for the average district in neither rural nor urban India.

\subsection{Why rural}

The empirical literature on trade liberalization so far has focused predominantly on the manufacturing sector, and urban areas because these were the areas most commonly affected by trade liberalization (Goldberg and Pavcnik, 2004). Thus, it is rather surprising that the effect 
of trade liberalization on districts is more pronounced in rural India than in urban India. ${ }^{19} \mathrm{~A}$ close look at the evolution of tariff and non-tariff barriers in Figure 1 suggests an explanation. Agriculture was not omitted from the 1991 reforms in India. Tariffs of agricultural products fell in line with tariffs of manufacturing and other goods. While quantity restrictions and licensing requirements on both the import and export of agricultural products (out of a concern for food security) were removed later than on other goods, the share of agricultural products that could be freely imported jumped from 7 percent in 1989 to 40 percent in 1998 . Between 1998 and 2001 this number reached more than 80 percent.

In addition, the agricultural tariffs and non-tariff barriers are strongly correlated. The postliberalization data (the 55th round of the NSS) was collected from mid 1999 to mid 2000, right when the bulk of the removal of NTB was taking place. Thus the tariff measure may be capturing the effect of both tariff and non-tariff barriers and reflect the short term effect of the change in relative price of agricultural products on the extensive rural population. I construct separate measures of agricultural tariffs and mining and manufacturing tariffs that a district faces and regress district poverty and inequality on these measures of trade policy. Table A2 in the appendix reveals that the results are driven by agricultural tariffs. ${ }^{20}$ There is little relationship between mining and manufacturing tariffs and district outcomes, though, due to the large standard errors of the point estimates, I can not reject for any of the outcomes and for any of the subsamples, that the effect of mining and manufacturing tariffs and of agricultural tariffs is the same. The finding is not that surprising; manufacturing and mining workers represent only 6 percent of workers in the typical rural district - thus it is plausible that even if trade liberalization had a sizeable effect on their wellbeing or relative earnings, it would not be reflected in district-level outcomes.

Furthermore, people involved in agriculture are the most vulnerable, often with little access to insurance devices. There is no shortage of press accounts on farmers committing suicide in the face of adverse shocks in India. Manufacturing workers, on the other hand, tend to be relatively

\footnotetext{
${ }^{19}$ On the other hand, rural areas are where the poor people in India are concentrated. At the eve of the 1991 reforms, both poverty rates and poverty depth were almost double in rural areas (40 versus 22.8 percent poverty rate and 9 versus 4.7 percent poverty depth).

${ }^{20}$ Note that the magnitudes of the coefficients in table A2 are not interpretable as the measures of agricultural and mining and manufacturing tariffs are not scaled by the share of population employed in the particular sector.
} 
richer than agricultural workers: significant decline in income may not be enough to push them below the poverty line.

\subsection{Robustness}

The effects of liberalization identified in this paper could be incorrect if measures of trade liberalization were correlated with omitted time-varying variables that affect poverty and inequality. In this section, I first examine whether districts with different initial industrial compositions were on different growth paths. I then determine whether pre-existing conditions within districts are correlated with subsequent tariff changes. Finally, I measure whether "initial" (1987) conditions other than industrial composition in districts are correlated with subsequent changes in poverty, and if so, whether they are driving the results.

To address the concern that districts with different industrial composition may be experiencing different time trends in poverty and inequality that are (spuriously) correlated with tariff changes, I perform a falsification test. In particular, I test whether changes in poverty and inequality in the two periods prior to the reform (from 1983 to 1987) are correlated with measures of trade liberalization from 1987 to1997. ${ }^{21}$ I use the four specifications (OLS, reduced form, and both IV specifications), but now using 1983 and 1987 outcomes as pre and post, rather than the 1987 and 1999 outcomes. The results are presented in Table 4. In both urban and rural areas, there seems to be no correlation between tariff changes and the pre-reform trend in any of the outcomes.

In Tables 5 and 6, I investigate the possibility that the results might be driven by convergence or omitted variables. ${ }^{22}$ I control for time-varying effect of various pre-reform district characteristics as well as initial levels of outcomes, by including the interaction of these initial characteristics and a post liberalization dummy, estimating:

$$
y_{d t}=\alpha+\beta \cdot \text { Tariff }_{d t}+\theta \cdot \text { Post }_{t} \cdot X_{d, 1987}+\gamma_{t}+\delta_{d}+\varepsilon_{d t}
$$

In all specifications I include in $X_{d, 1987}$ initial industrial composition in the district (namely

\footnotetext{
${ }^{21}$ Note that the analysis can be performed only at the region level as district identifiers are not available in the 38 th round of the NSS.

${ }^{22}$ I present the analysis only for the rural sample from now on as the effect of trade liberalization in the urban sector can not be precisely estimated.
} 
percentage of workers in agriculture, manufacturing, mining, trade, transport, services - workers in construction are the omitted category), percentage literate and the share of scheduled caste and scheduled tribes population. I sequentially add as controls the initial level of the log of mean per capita expenditure in the district, the pre-reform trend in the outcome variable (the difference between its 1983 and 1987 value), and finally the initial value of the dependent variable itself instrumented by its value in 1983. I also allow for differential time trends in district outcomes across states with pro-employer, pro-worker and neutral labor laws by including post times labor law fixed effects. ${ }^{23}$ In columns (1)-(4), I use only $\operatorname{TrTariff}_{d, t}$ as an instrument for Tariff ${ }_{d, t}$, while in columns (5)-(8), I instrument the scaled tariff with both TrTariff ${ }_{d, t}$, and the initial level interacted with a post liberalization dummy. Columns (4) and (8) include the instrumented value of the lagged dependent variable, where the 1983 level is used as an instrument for the 1987 level. $^{24}$

The inclusion of district initial characteristics does not substantially change the results at the district level. Controlling for initial per-capita expenditure or pre-reform outcome reduces the size of the point estimates (from 0.8 to 0.44 for poverty rate and from 0.32 to 0.12 for poverty gap when the non-scaled tariff is the only instrument, and from 0.68 to 0.45 for poverty rate and from 0.21 to 0.12 for poverty gap when both the non-scaled tariff and its initial level are used as instruments). It may be that some of the variation in poverty depth and incidence that equation 1 attributed to trade liberalization was in fact due to convergence. According to these corrected estimates, the decline in tariffs increased relative poverty incidence by about 2 and poverty gap by 0.6 percentage points in the average district.

I also address the concern that some other reforms concurrent with trade liberalization may be driving the results. In particular, in 1991 the government of India increased the number of de-licensed industries and specified a list of industries for automatic approval for foreign direct investment. ${ }^{25}$ Substantial reforms were initiated in the financial and banking sector

\footnotetext{
${ }^{23}$ Indian states are classified as having pro-worker, neutral, or pro-employer labor laws by Besley and Burgess (2004).

${ }^{24}$ Including the actual value would be equivalent to regressing changes on levels: if there is mean reversion and measurement error, the coefficient could be biased. In fact, the size of the coefficient on the initial level of the outcomes suggests implausibly strong convergence.

${ }^{25}$ Foreign investment was tightly regulated prior to 1991 . Foreign companies needed to obtain specific prior approval from the Indian government and foreign investment was limited to 40 percent. In 1991, the government
} 
as well. Following the same methodology as in the construction of district tariffs, I construct district employment-weighted share of license-industries and district employment-weighted share of industries that are open to foreign direct investment. ${ }^{26}$ The number of bank branches per capita in a district captures the potentially confounding effect of banking reforms. ${ }^{27}$

In Table 6, I replicate the specifications presented in Table 5 including these time-varying district level measures of reforms. The effect of trade liberalization on poverty is completely insensitive to the additional controls. There is no correlation between poverty and the number of bank branches per capita nor share of industries under a license. A larger share of industries open to FDI, however, is associated with faster reduction in poverty. As globalization is typically defined not only as trade liberalization but also opening to foreign investment, it is important to emphasize this finding. It also reconciles Gordon Hanson's conclusion in another paper with similar methodology in this volume that more globalized areas in Mexico experienced a larger increase in labor income with the finding that trade liberalization slowed poverty reduction in more exposed districts in India. Hanson's definition of exposure to globalization takes into account the share of maquiladora value added in state GDP, the share of FDI in state GDP, and the share of imports and exports in state GDP, while the main findings of this study concern the consequences of tariff liberalization.

In Table A3 in the appendix I investigate the role of imports versus exports, in addition to FDI, by including the district employment-weighted industry imports and exports. I use 1987 import/export data for the pre-reform period, and the 1993-1997 annual average for the postreform period. Since imports and exports are the endogenous response to trade policy, exchange rate shocks, foreign demand etc., these regressions do not warrant a causal interpretation, yet they illustrate that imports are associated with higher, while exports with lower incidence of poverty. These correlations are in-line with the findings in Goldberg and Pavcnik's study in this created a list of high technology and high investment priority industries with automatic permission for foreign equity share up to 51 percent. Over the 1990s this list was gradually expanded.

${ }^{26}$ Data on policies regarding industrial delicensing and opening to foreign direct investment were compiled from various publications of the Handbook of Industrial Statistics.

${ }^{27}$ The Indian government heavily regulates private and public banks, as it considers the banking system an integral tool in its efforts to meet a number of social goals, such as poverty reduction. Indeed, Burgess and Pande (2004) have shown that rural bank branch expansion over the 1980s lead to reduction in poverty. 
volume. Goldberg and Pavcnik investigate the effect of Colombia's trade liberalization on urban unemployment, informality, minimum wage compliance and poverty, by exploiting variation in the timing and magnitude of tariff reductions across manufacturing sectors. While they find no robust relationship between tariff changes and various labor market outcomes, higher exposure to import competition is associated with greater likelihood of unemployment, informality and poverty, while higher exports correlate with lower informality, poverty and better minimum wage compliance.

\section{Discussion and Conclusion}

So far this paper has established that, whatever the India-wide effects of trade liberalization were, rural areas with high concentration of industries that were disproportionately affected by tariff reductions, experienced slower progress in poverty reduction. However, for these areas, there was no discernible effect on inequality.

The regionally disparate effects of liberalization are not consistent with standard trade theory. In the hypothetical world of a standard trade model, with perfect factor mobility across regions, labor would migrate in response to wage and price shocks, equalizing the incidence of poverty across regions. Estimating equation 1 would yield an estimate of $\beta$ equal to zero, indicating that the local intensity of liberalization has no effect on local poverty.

The interpretation of estimates of equation 1 as effects of liberalization on regional outcomes is correct only if labor is immobile across geographical districts within India in the short to medium-run, that is, if each district represents a separate labor market. While this represents an immediate departure from standard trade theory, the assumption is realistic for the case of India: the absence of mobility is striking. Moreover, the pattern of migration has remained remarkably constant through time, with no visible increase after the economic reforms of 1991.

Table 7 presents some estimates of migration for urban and rural India based on the 3 rounds of the NSS $(1983,1987$ and 1999) that included questions on the migration particulars of household members. Overall migration is not low - 20-23 percent of rural and 31-33 percent of urban residents have changed location of residence at least once in their lifetime. Most migrants are women relocating at marriage: around 40 percent of females in rural and urban India report 
a change in location, versus 7 percent of men in rural and 26 percent of men in urban locations. However, the migration most relevant for this study is short-run movement (within the past 10 years) of people across district boundaries or within district across different sectors (i.e. from an urban area to a rural one, or vice versa). Only 3-4 percent of people living in rural areas reported changing either district or sector within the past 10 years. Again the percentage of women so doing is double the share of men. For people living in urban areas, the percentage of migrants is substantially higher. Yet, less than 0.5 percent of the population in rural and 4 percent of the population in urban areas moved for reasons economic consideration (or employment).

These low migration figures combined with a second characteristic of India's economy, namely the large and growing disparities in income across Indian states, challenge the standard theoretical framework. Ahluwalia(2001), Datt and Ravallion (2002), Sachs et al. (2002), Bandyopadhyay (2003) and others document significant differences in the level of state GDP per capita and growth rate of state output.

Even if there is little migration across districts, there could be high levels of reallocation within districts, across industries. Topalova (2004b) examines whether, as standard trade theory predicts, there is intersectoral reallocation of labor and capital. There is no evidence of significant reallocation in the sample of all Indian states, though in the sample of Indian states with flexible labor laws, ${ }^{28}$ employment is positively correlated with industry tariffs. This correlation is consistent with previous findings of faster growth of output and employment (Besley and Burgess, 2004) and a higher elasticity of labor demand with respect to output price in states with flexible labor laws (Hasan et al., 2003). Topalova (2004b) also examines whether these differences in the institutional environment and microeconomic flexibility affected the impact of liberalization: the most pronounced effects on poverty occurred in areas with inflexible labor laws (those that saw no change in industrial structure in response to trade liberalization) while inequality rose as a result of trade liberalization in areas with flexible labor laws.

Topalova (2004b) further investigates whether the adjustment came through the price system, by looking at the effect of tariff changes on wages and wage premia and finds substantial

\footnotetext{
${ }^{28}$ Besley and Burgess (2004) classify Indian states as pro-worker, pro-employer or neutral, based on amendments of the Industrial Disputes Act. Hasan et al. (2003) combine these categories with the ranking of the investment climate in Indian states from a survey of managers conducted by the World Bank, in order to classify states as having flexible or inflexible labor laws. Topalova (2004b) adopts Hasan et al. (2003)'s classification.
} 
adjustment in wages and industry premia, including industry premia of agricultural workers. In the next paper in this volume Goh and Javorcik find that in Poland, workers in sectors with the largest tariff declines experienced the highest increase in wages; in India, these workers suffered the highest relative decrease in wage premia. Goh and Javorcik posit that in Poland's case, firms responded to higher import competition by increasing productivity and rewarded the increased labor productivity with higher wages. Topalova (2004a) finds similar results in India: micro evidence suggests that firms in industries that were relatively more liberalized experienced higher productivity and productivity growth. However, in India, these trade induced productivity increases were likely not shared with the workers or were insufficient to offset the relative downward pressure on factor returns.

The mechanisms discussed above are consistent with a specific factor model of trade in which labor is the specific factor in the short run. Rigid labor markets fostered by labor market regulations in parts of India prevented the reallocation of factors in the face of trade liberalization in those areas. Changes in relative output prices led to changes in relative sector-returns to the specific factors. As those employed in traded industries were not at the top of the income distribution on the eve of the trade reform, the relative fall in wages contributed to the slower poverty reduction. This effect was aggravated by the slower overall growth in registered manufacturing employment in areas with inflexible labor laws, which retarded the pull out of poverty of the poorest subsistence farmers. In contrast, areas in which reallocation was easier, and growth was faster (because of labor laws), were shielded from the effect of trade liberalization. In those areas, the changes in the income distribution seem to have taken place in the high end, as some workers tapped into the benefits of liberalization, thereby increasing the consumption inequality.

This is the first (to my knowledge) study to document such a relationship between trade liberalization and poverty within a developing or developed country. The findings are important from a policy perspective as an increasing number of developing countries pursue policies of trade liberalization, hoping to boost economic growth, raise living standards, and reduce poverty. This paper does not measure the overall effect of trade liberalization on income growth and poverty alleviation. There was a substantial reduction in poverty in India over the 1990s, which trade reforms may have boosted of slowed down. This paper establishes that different regions within India experienced differential effects of trade liberalization. Those areas that were more exposed 
to potential foreign competition did not reap as much of the benefits (or bore a disproportionate share of the burden) of liberalization in terms of poverty reduction.

A critical component to the findings of this study, as well as the study on Colombia in this volume, is the absence of labor mobility in the short- to medium-run. Workers do not relocate from sectors that should be contracting to those that should be expanding fast enough, thus impeding one of the main mechanisms generating benefits from trade. Enhancing labor mobility will likely minimize the adjustment costs to trade opening. This study presents some evidence to this effect: the impact of trade on relative poverty in India was most pronounced in areas with inflexible labor laws, where labor mobility was hindered. If some of the immobility of labor is institutionally driven, then complementary measures to trade opening, such as labor market reform, can ease the shock of liberalization and minimize its unequalizing effects.

\section{References}

Ahluwalia, Montek. "India's Economic Reforms. An Appraisal" in India in the Era of Economic Reforms eds. J. Sachs, A. Varshney and N. Bajpai, 1999.

Ahluwalia, Montek. "Economic Reforms in India Since 1991: Has Gradualism Worked?" Journal of Economic Perspectives, 2002, 16(3), pp. 67-88.

Ahluwalia, Montek. "State-Level Performance Under Economic Reforms in India?" in Economic policy reforms and the Indian economy, 2002, pp. 91-122.

Aksoy, M. A. "The Indian Trade Regime." The World Bank Working Paper Series No. 989, 1992.

Attanasio, Orazio, Pinelopi Goldberg and Nina Pavcnik. "Trade Reforms and Wage Inequality in Columbia." Journal of Development Economics, 2004, 74(2), pp. 331-366.

Bandyopadhyay, Sanghamitra. "Convergence Club Empirics: Some Dynamics and Explanations of Unequal Growth across Indian States." Suntory and Toyota International Centres for Economics and Related Working Paper, 2003. 
Banerjee, Abhijit and Andrew Newman. "Inequality, Growth and Trade Policy." mimeo, MIT, 2004.

Besley, Timothy and Robin Burgess. "Can Labor Regulation Hinder Economic Performance? Evidence from India." Quarterly Journal of Economics, 2004, 119(1), pp. 91-134.

Bhagwati, Jagdish. India in Transition: Freeing the Economy, Oxford University Press, 1993.

Burgess, Robin and Rohini Pande. "Can Rural Banks Reduce Poverty? Evidence from the Indian Social Banking Experiment.” forthcoming, American Economic Review.

Cerra, Valerie and Sweta Saxena. "What Caused the 1991 Currency Crisis in India?" International Monetary Fund Working Paper No. 00/157, October 2000.

Chopra, Ajai, Charles Collyns, Richard Hemming, Karen Parker, Woosik Chu and Oliver Fratzscher. "India: Economic Reform and Growth." International Monetary Fund Occasional Paper No. 134, December 1995.

Cragg, Michael Ian and Mario Epelbaum. "Why Has Wage Dispersion Grown in Mexico? Is it the Incidence of Reforms or the Growing Demand for Skills?" Journal of Development Economics, 1996, 51(1), pp. 99-116.

Cunat, A. and M. Maffezzoli. "Growth and Interdependence Under Complete Specialization." Bocconi University Working Paper No. 183, 2001.

Currie, Janet and Ann Harrison. "Sharing the Costs: The Impact of Trade Reform on Capital and Labor in Morocco." Journal of Labor Economics, 1997, 15(3), Part 2, pp. 44-71.

Datt, Gaurav and Martin Ravallion. "Is India's Economic Growth Leaving the Poor Behind." Journal of Economic Perspectives, 2002, 16(3), pp. 89-108.

Davis, Donald. "Trade Liberalization and Income Distribution." National Bureau of Economic Research Working Paper No. 5693, 1996.

Deaton, Angus. (a) "Adjusted Indian Poverty Estimates for 1999-2000." Economic and Political Weekly, 2003, pp. 322-326. 
Deaton, Angus. (b) "Prices and Poverty in India, 1987-2000." Economic and Political Weekly, 2003, pp. 362-368.

Deaton, Angus and Jean Dreze. "Poverty and Inequality in India: A Reexamination." Economic and Political Weekly, 2002, pp. 3729-3748.

Deaton, Angus and Alessandro Tarozzi. "Prices and Poverty in India." mimeo, 2000.

Debroy B. and A. T. Santhanam. "Matching Trade Codes with Industrial Codes." Foreign Trade Bulletin, 1993, 24(1).

Dollar, David and Aart Kraay. "Growth is Good for the Poor." Journal of Economic Growth, 2002, 7(3), pp. 195-225.

Edwards, Sebastian. "Openness, Productivity and Growth. What Do We Really Know?" Economic Journal, 1998, 108(447), pp. 383-398.

Feenstra Robert and Gordon Hanson. "Foreign Direct Investment and Relative Wages: Evidence from Mexico's Maquiladoras." Journal of International Economics, 1997, 42(2), pp. 371-393.

Feliciano, Zadia. "Workers and Trade Liberalization: The Impact of Trade Reforms in Mexico on Wages and Employment." Industrial and Labor Relations Review, 2001, 55(1), pp. 95-115.

Gang, Ira and Mihir Pandey. "Trade Protection in India: Economics vs. Politics?" University of Maryland Working Paper No. 27, December 1996.

Goldberg, Pinelopi and Nina Pavcnik. "Trade Protection and Wages: Evidence from the Colombian Trade Reforms." NBER Working Paper No. 8575, November 2001.

Goldberg, Pinelopi and Nina Pavcnik. "Trade, Inequality, and Poverty: What Do We Know? Evidence from Recent Trade Liberalization Episodes in Developing Countries." NBER Working Paper No. 10593, June 2004.

Goldberg, Pinelopi and Nina Pavcnik. "The Effects of the Colombian Trade Liberalization on Urban Poverty." October 2004, this volume. 
Goldar, Bishwanath. "Trade Liberalization and Manufacturing Employment." International Labor Organization Employment Paper 2002/34, 2002.

Goyal, S.K. "Political Economy of India's Economic Reforms." Institute for Studies in Industrial Development (ISID) Working Paper, October 1996.

Grossman, Gene and Elhanan Helpman. Interest Group and Trade Policy, Princeton University Press, 2002.

Hanson, Gordon and Ann Harrison. "Trade and wage inequality in Mexico." Industrial and Labor Relations Review, 1999, 52(2), pp. 271-288.

Harrison, Ann and Gordon Hanson. "Who Gains From Trade Reform? Some Remaining Puzzles." Journal of Development Economics, 1999, 59(1), pp. 125-154.

Hasan, Rana. "The Impact of Imported and Domestic Technologies on the Productivity of Firms: Panel Data Evidence From Indian Manufacturing Firms." Journal of Development Economics, 2002, 69(1), pp. 23-49.

Hasan, Rana, Devashish Mitra and K. V. Ramaswamy. "Trade Reforms, Labor Regulations and Labor Demand Elasticities: Evidence from India." NBER Working Paper No. 9879, August 2003.

Kremer, Michael and Eric Maskin. "Globalization and Inequality." mimeo, 2003.

Lundberg, Mattias and Lyn Squire. "The simultaneous Evolution of Growth and Inequality." Economic Journal, 2003, 113(487), pp. 326-344.

Milanovic, Branko. "Can We Discern the Effect of Globalization on Income Distribution? Evidence from Household Budget Surveys.” World Bank Research Paper 2876, 2002.

Porto, Guido. "Trade Reforms, Market Access and Poverty in Argentina." World Bank mimeo, 2004.

Rama, Martin. "Globalization and the Labor Market." World Bank Research Observer, 2003, 18(2), pp. 159-186. 
Revenga, Ana. "Employment and Wage Effects of Trade Liberalization: The Case of Mexican Manufacturing." Journal of Labor Economics, 1996, 15(3), pp. 20-43.

Sachs, Jeffrey, Nirupam Bajpai and Ananthi Ramiath. "Understanding Regional Economic Growth in India.” CID Working Paper No. 88, March 2002.

Stiglitz, Joseph. "Factor Price Equalization in a Dynamic Economy." Journal of Political Economy, 1970, 78(3), pp. 456-488.

Topalova, Petia. (a) "The Effect of Trade Liberalization on Productivity: The Case of India." IMF Working Paper No. 04/28, February 2004.

Topalova, Petia. (b) "Factor Immobility and Regional Effects of Trade Liberalization: Evidence from India." MIT mimeo, October 2004.

Varshney, Ashutosh. "Mass Politics or Elite Politics? India's Economic Reforms in Comparative Perspective." in India in the Era of Economic Reforms eds. J. Sachs, A. Varshney and N. Bajpai, 1999.

Verhoogen, Eric. "Trade, Quality Upgrading and Wage Inequality in the Mexican Manufacturing Sector: Theory and Evidence from an Exchange-Rate Shock." Center for Labor Economics, UC Berkeley, Working Paper No. 67, January 2004. 
Table 1. Tariff Declines and Pre-Reform Industrial Characteristics

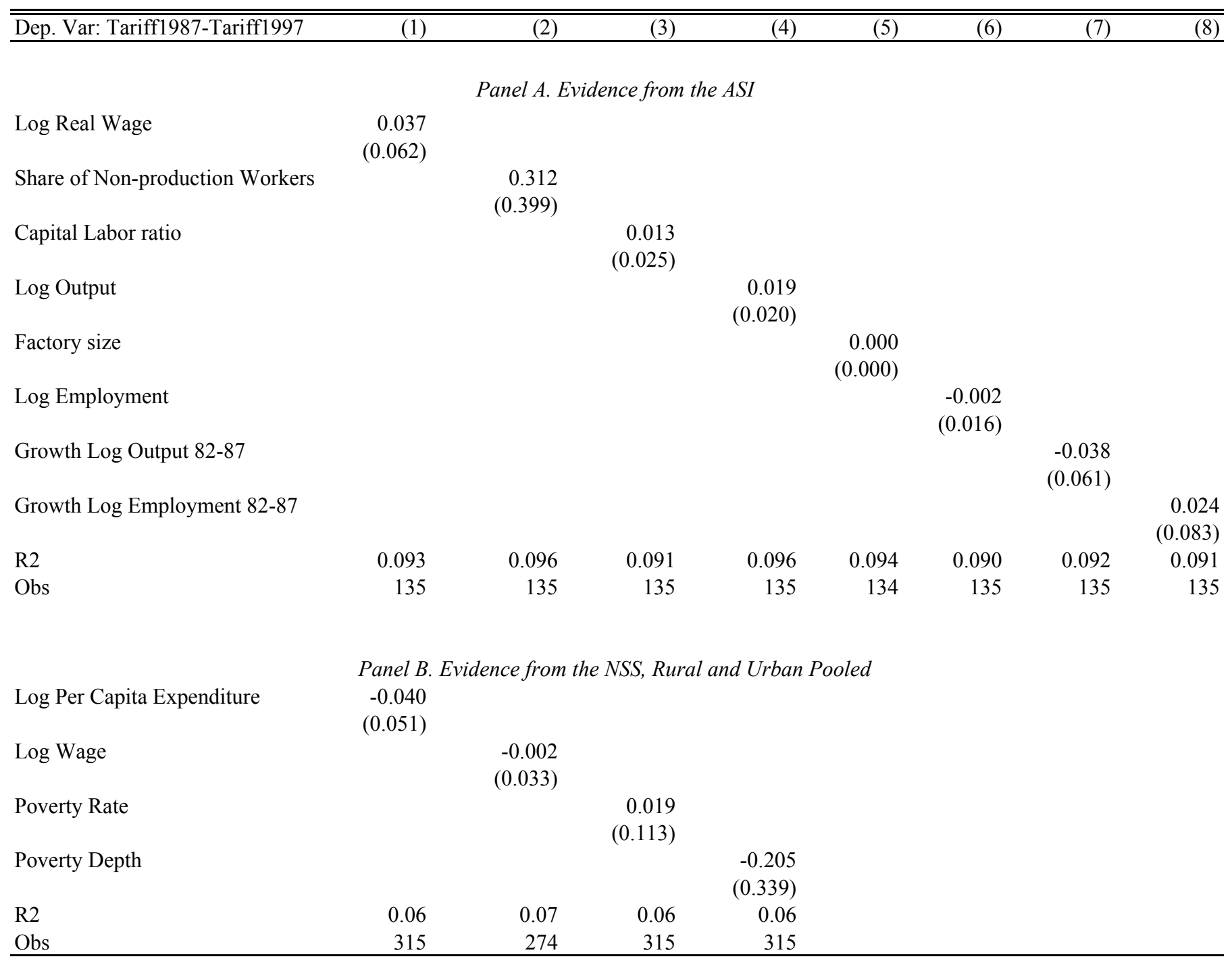

Note: Robust standard errors in parentheses. Significance at the 10 percent level of confidence is represented by a $*$, at the 5 percent level by **, and at the 1 percent level by ***. All regressions include indicators for industry use type: i.e. Capital goods, Consumer Durables, Consumer Non Durables, and Intermediate. In Panel A, regressions are weighted by the square root of the number of factories. Data are from the 1987 ASI and cover mining and manufacturing industries. In Panel B, regressions are weighted by the square root of the number of workers in each industry in the 1987 NSS. Urban and Rural sample are pooled and an indicator for urban is included. Separate regressions for the urban and rural sample exhibit similar patterns. Note that cereals and oilseeds cultivation has been treated as a non-traded industry, because imports of these agricultural products were canalized (restricted only to state trading monopolies) until 2000. 
Table 2. First Stage. Relationship Between Scaled and Non-Scaled Tariffs

\begin{tabular}{lccccc}
\hline \hline \multirow{2}{*}{ DepVar: Tariff } & \multicolumn{2}{c}{ I. RURAL } & & \multicolumn{2}{c}{ II. URBAN } \\
\cline { 2 - 3 } \cline { 5 - 6 } & $(1)$ & $(2)$ & & $(3)$ & $(4)$ \\
\hline \multirow{2}{*}{ TrTariff } & $0.356^{* * *}$ & $0.633^{* * *}$ & & $0.407 * * *$ & $0.687 * * *$ \\
& $(0.090)$ & $(0.089)$ & & $(0.091)$ & $(0.150)$ \\
TrTariff*Post & & $0.288^{* * *}$ & & & $0.214^{*}$ \\
& & $(0.051)$ & & & $(0.118)$ \\
& & & & 0.91 & 0.91 \\
R2 & 0.84 & 0.86 & & 724 & 724 \\
Obs & 728 & 728 & &
\end{tabular}

Note: All regressions include year and district dummies. Standard errors (in parentheses) are corrected for clustering at the state year level. Regressions are weighted by the square root of the number of people in a district. Significance at the 10 percent level of confidence is represented by $\mathrm{a} *$, at the 5 percent level by $* *$, and at the 1 percent level by $* * *$. 
Table3. Effect of Trade Liberalization on Poverty and Inequality in Indian Districts

\begin{tabular}{|c|c|c|c|c|c|c|c|c|}
\hline & \multicolumn{4}{|c|}{ I. RURAL } & \multicolumn{4}{|c|}{ II. URBAN } \\
\hline & Tariff & TrTariff & $\begin{array}{r}\text { IV- } \\
\text { TrTariff }\end{array}$ & $\begin{array}{l}\text { IV-TrTariff, } \\
\text { Init TrTariff }\end{array}$ & Tariff & TrTariff & $\begin{array}{r}\text { IV- } \\
\text { TrTariff }\end{array}$ & $\begin{array}{l}\text { IV-TrTariff, } \\
\text { Init TrTariff }\end{array}$ \\
\hline & $(1)$ & $(2)$ & $(3)$ & $(4)$ & $(5)$ & $(6)$ & $(7)$ & $(8)$ \\
\hline \multicolumn{9}{|c|}{ Panel A. Dependent variable: Poverty Rate } \\
\hline Tariff Measure & $\begin{array}{l}-0.287 * * \\
(0.118)\end{array}$ & $\begin{array}{l}-0.297 * * * \\
(0.084)\end{array}$ & $\begin{array}{l}-0.834 * * * \\
(0.250)\end{array}$ & $\begin{array}{l}-0.687 * * * \\
(0.225)\end{array}$ & $\begin{array}{r}-0.215 \\
(0.190)\end{array}$ & $\begin{array}{r}-0.065 \\
(0.156)\end{array}$ & $\begin{array}{r}-0.156 \\
(0.353)\end{array}$ & $\begin{array}{r}-0.403 \\
(0.275)\end{array}$ \\
\hline Obs & 725 & 725 & 725 & 725 & 703 & 703 & 703 & 703 \\
\hline \multicolumn{9}{|c|}{ Panel B. Dependent variable: Poverty Gap } \\
\hline Tariff Measure & $\begin{array}{l}-0.129 * * * \\
(0.038)\end{array}$ & $\begin{array}{l}-0.114 * * * \\
(0.021)\end{array}$ & $\begin{array}{l}-0.319 * * * \\
(0.073)\end{array}$ & $\begin{array}{l}-0.206 * * * \\
(0.075)\end{array}$ & $\begin{array}{r}-0.084 \\
(0.052)\end{array}$ & $\begin{array}{r}-0.032 \\
(0.046)\end{array}$ & $\begin{array}{r}-0.076 \\
(0.101)\end{array}$ & $\begin{array}{r}-0.131 \\
(0.087)\end{array}$ \\
\hline Obs & 725 & 725 & 725 & 725 & 703 & 703 & 703 & 703 \\
\hline \multicolumn{9}{|c|}{ Panel C. Dependent variable: StdLog Consumption } \\
\hline Tariff Measure & $\begin{array}{r}-0.086 \\
(0.154)\end{array}$ & $\begin{array}{r}-0.094 \\
(0.082)\end{array}$ & $\begin{array}{l}-0.265 \\
(0.228)\end{array}$ & $\begin{array}{r}-0.161 \\
(0.183)\end{array}$ & $\begin{array}{r}0.092 \\
(0.094)\end{array}$ & $\begin{array}{r}0.108 \\
(0.115)\end{array}$ & $\begin{array}{r}0.257 \\
(0.295)\end{array}$ & $\begin{array}{r}0.213 \\
(0.250)\end{array}$ \\
\hline Obs & 725 & 725 & 725 & 725 & 703 & 703 & 703 & 703 \\
\hline \multicolumn{9}{|c|}{ Panel D. Dependent variable: Log Deviation of Consumption } \\
\hline Tariff Measure & $\begin{array}{r}-0.016 \\
(0.066)\end{array}$ & $\begin{array}{r}-0.020 \\
(0.042)\end{array}$ & $\begin{array}{r}-0.057 \\
(0.115)\end{array}$ & $\begin{array}{r}-0.020 \\
(0.071)\end{array}$ & $\begin{array}{r}0.034 \\
(0.062)\end{array}$ & $\begin{array}{r}0.090 \\
(0.066)\end{array}$ & $\begin{array}{r}0.215 \\
(0.174)\end{array}$ & $\begin{array}{r}0.172 \\
(0.144)\end{array}$ \\
\hline Obs & 725 & 725 & 725 & 725 & 703 & 703 & 703 & 703 \\
\hline
\end{tabular}

Note: All regressions include year and district dummies. Standard errors (in parentheses) are corrected for clustering at the state year level. Regressions are weighted by the square root of the number of people in a district. Significance at the 10 percent level of confidence is represented by a $*$, at the 5 percent level by $* *$, and at the 1 percent level by $* * *$. 
Table 4. Pre-Reform Test. Correlation Between Pre-Reform Trends in Outcomes and Tariff Change

\begin{tabular}{|c|c|c|c|c|c|c|c|c|}
\hline & \multicolumn{4}{|c|}{ I. RURAL } & \multicolumn{4}{|c|}{ II. URBAN } \\
\hline & $\frac{\text { OLS }}{(1)}$ & $\frac{R F}{(2)}$ & $\begin{array}{r}\begin{array}{r}\text { IV- } \\
\text { TrTariff }\end{array} \\
(3)\end{array}$ & $\begin{array}{l}\text { IV-TrTariff, } \\
\text { Init TrTariff } \\
(4)\end{array}$ & $\frac{\text { OLS }}{(5)}$ & $\frac{\mathrm{RF}}{(6)}$ & $\begin{array}{r}\begin{array}{r}\text { IV- } \\
\text { TrTariff }\end{array} \\
(7)\end{array}$ & $\begin{array}{l}\text { IV-TrTariff, } \\
\text { Init TrTariff } \\
(8)\end{array}$ \\
\hline \multicolumn{9}{|c|}{ Panel A. Dependent variable: Poverty Rate } \\
\hline Tariff Change & $\begin{array}{r}0.065 \\
(0.571)\end{array}$ & & $\begin{array}{r}0.842 \\
(0.851)\end{array}$ & $\begin{array}{r}0.746 \\
(0.762)\end{array}$ & $\begin{array}{r}-0.092 \\
(0.373)\end{array}$ & & $\begin{array}{r}0.274 \\
(0.563)\end{array}$ & $\begin{array}{r}0.375 \\
(0.576)\end{array}$ \\
\hline TrTariff Change & & $\begin{array}{r}0.333 \\
(0.326)\end{array}$ & & & & $\begin{array}{r}0.148 \\
(0.289)\end{array}$ & & \\
\hline R2 & 0.001 & 0.033 & & & 0.002 & 0.004 & & \\
\hline Obs & 62 & 62 & 62 & 62 & 60 & 60 & 60 & 60 \\
\hline \multicolumn{9}{|c|}{ Panel B. Dependent variable: Poverty Gap } \\
\hline Tariff Change & $\begin{array}{r}0.007 \\
(0.197)\end{array}$ & & $\begin{array}{r}0.114 \\
(0.273)\end{array}$ & $\begin{array}{r}0.091 \\
(0.240)\end{array}$ & $\begin{array}{r}-0.079 \\
(0.117)\end{array}$ & & $\begin{array}{r}-0.194 \\
(0.238)\end{array}$ & $\begin{array}{r}-0.170 \\
(0.211)\end{array}$ \\
\hline TrTariff Change & & $\begin{array}{r}0.045 \\
(0.108)\end{array}$ & & & & $\begin{array}{r}-0.105 \\
(0.128)\end{array}$ & & \\
\hline $\mathrm{R} 2$ & 0.000 & 0.003 & & & 0.013 & 0.016 & & \\
\hline Obs & 62 & 62 & 62 & 62 & 60 & 60 & 60 & 60 \\
\hline \multicolumn{9}{|c|}{ Panel C. Dependent variable: StdLog Consumption } \\
\hline Tariff Change & $\begin{array}{r}0.178 \\
(0.131)\end{array}$ & & $\begin{array}{r}0.008 \\
(0.287)\end{array}$ & $\begin{array}{r}-0.119 \\
(0.260)\end{array}$ & $\begin{array}{l}-0.055 \\
(0.170)\end{array}$ & & $\begin{array}{r}0.180 \\
(0.320)\end{array}$ & $\begin{array}{r}0.025 \\
(0.260)\end{array}$ \\
\hline TrTariff Change & & $\begin{array}{r}0.003 \\
(0.114)\end{array}$ & & & & $\begin{array}{r}0.097 \\
(0.160)\end{array}$ & & \\
\hline $\mathrm{R} 2$ & 0.027 & 0.000 & 0.002 & & 0.002 & 0.004 & & \\
\hline Obs & 62 & 62 & 62 & 62 & 60 & 60 & 60 & 60 \\
\hline \multicolumn{9}{|c|}{ Panel D. Dependent variable: Log Deviation of Consumption } \\
\hline Tariff Change & $\begin{array}{r}0.074 \\
(0.071)\end{array}$ & & $\begin{array}{r}-0.023 \\
(0.141)\end{array}$ & $\begin{array}{r}-0.094 \\
(0.119)\end{array}$ & $\begin{array}{c}-0.102 \\
(0.107)\end{array}$ & & $\begin{array}{r}0.118 \\
(0.213)\end{array}$ & $\begin{array}{r}0.041 \\
(0.169)\end{array}$ \\
\hline TrTariff Change & & $\begin{array}{r}-0.009 \\
(0.055)\end{array}$ & & & & $\begin{array}{r}0.064 \\
(0.108)\end{array}$ & & \\
\hline $\mathrm{R} 2$ & 0.011 & 0.000 & & & 0.013 & 0.004 & & \\
\hline Obs & 62 & 62 & 62 & 62 & 60 & 60 & 60 & 60 \\
\hline
\end{tabular}

Note: Standard errors (in parentheses) are corrected for clustering at the state level. Regressions are weighted by the square root of the number of people in the region. Dependent variables are Outcome1983 minus Outcome1987.

Significance at the 10 percent level of confidence is represented by a *, at the 5 percent level by **, and at the 1 percent level by $* * *$. 
Table 5. Effect of Trade Liberalization on Poverty and Inequality in Rural India Controlling for Initial Characteristics and Other Reforms

\begin{tabular}{|c|c|c|c|c|c|c|c|c|}
\hline & \multicolumn{4}{|c|}{ I. IV-TrTariff } & \multicolumn{4}{|c|}{ II. IV-TrTariff, Init TrTariff } \\
\hline & $(1)$ & $(2)$ & (3) & $(4)$ & $(5)$ & $(6)$ & $(7)$ & $(8)$ \\
\hline \multicolumn{9}{|c|}{ Panel A. Dependent variable: Poverty Rate. District Level $(\mathrm{Obs}=725)$} \\
\hline Tariff Measure & $\begin{array}{l}-0.607 * * * \\
(0.232)\end{array}$ & $\begin{array}{l}-0.434 * * \\
(0.217)\end{array}$ & $\begin{array}{r}-0.441 \\
(0.281)\end{array}$ & $\begin{array}{l}-0.444 * * \\
(0.208)\end{array}$ & $\begin{array}{l}-0.418 * * * \\
(0.141)\end{array}$ & $\begin{array}{l}-0.426 \text { *** } \\
(0.163)\end{array}$ & $\begin{array}{l}-0.522 * * \\
(0.206)\end{array}$ & $\begin{array}{l}-0.456 * * * \\
(0.134)\end{array}$ \\
\hline Logmean & & $\begin{array}{l}0.469 \text { *** } \\
(0.035)\end{array}$ & $\begin{array}{l}0.340 \\
(0.044)\end{array}$ & & & $\begin{array}{l}0.469 * * * \\
(0.034)\end{array}$ & $\begin{array}{l}0.338 * * * \\
(0.041)\end{array}$ & \\
\hline Trend & & & $\begin{array}{l}-0.322 * * * \\
(0.067)\end{array}$ & & & & $\begin{array}{l}-0.322 * * * \\
(0.067)\end{array}$ & \\
\hline Lagged 43 & & & & $\begin{array}{l}-0.419 \text { *** } \\
(0.123)\end{array}$ & & & & $\begin{array}{l}-0.417 \text { *** } \\
(0.120)\end{array}$ \\
\hline \multicolumn{9}{|c|}{ Panel B. Dependent variable: Poverty Gap. District Level $(O b s=725)$} \\
\hline Tariff Measure & $\begin{array}{l}-0.235 * * * \\
(0.075)\end{array}$ & $\begin{array}{l}-0.175 * * * \\
(0.066)\end{array}$ & $\begin{array}{l}-0.196 * * \\
(0.090)\end{array}$ & $\begin{array}{l}-0.118 * \\
(0.069)\end{array}$ & $\begin{array}{l}-0.121 * * \\
(0.062)\end{array}$ & $\begin{array}{l}-0.124 * * \\
(0.063)\end{array}$ & $\begin{array}{l}-0.177 * * \\
(0.080)\end{array}$ & $\begin{array}{l}-0.118 \text { *** } \\
(0.041)\end{array}$ \\
\hline Logmean & & $\begin{array}{l}0.161 \text { *** } \\
(0.015)\end{array}$ & $\begin{array}{l}0.126^{* * *} \\
(0.013)\end{array}$ & & & $\begin{array}{l}0.162 \text { *** } \\
(0.015)\end{array}$ & $\begin{array}{l}0.126 \text { *** } \\
(0.013)\end{array}$ & \\
\hline Trend & & & $\begin{array}{l}-0.319 * * * \\
(0.064)\end{array}$ & & & & $\begin{array}{l}-0.318 * * * \\
(0.064)\end{array}$ & \\
\hline Lagged 43 & & & & $\begin{array}{l}-0.576 \text { *** } \\
(0.144)\end{array}$ & & & & $\begin{array}{l}-0.576^{* * *} \\
(0.131)\end{array}$ \\
\hline \multicolumn{9}{|c|}{ Panel C. Dependent variable: StdLog Consumption. District Level $(O b s=725)$} \\
\hline Tariff Measure & $\begin{array}{r}-0.192 \\
(0.258)\end{array}$ & $\begin{array}{r}-0.244 \\
(0.260)\end{array}$ & $\begin{array}{c}-0.258 \\
(0.249)\end{array}$ & $\begin{array}{l}-0.057 \\
(0.232)\end{array}$ & $\begin{array}{r}-0.083 \\
(0.197)\end{array}$ & $\begin{array}{l}-0.078 \\
(0.203)\end{array}$ & $\begin{array}{r}-0.175 \\
(0.187)\end{array}$ & $\begin{array}{r}0.006 \\
(0.202)\end{array}$ \\
\hline Logmean & & $\begin{array}{l}-0.140 \text { *** } \\
(0.035)\end{array}$ & $\begin{array}{r}-0.047 \\
(0.040)\end{array}$ & & & $\begin{array}{l}-0.136 \text { *** } \\
(0.035)\end{array}$ & $\begin{array}{r}-0.045 \\
(0.041)\end{array}$ & \\
\hline Trend & & & $\begin{array}{l}-0.635 * * * \\
(0.063)\end{array}$ & & & & $\begin{array}{l}-0.635 * * * \\
(0.063)\end{array}$ & \\
\hline Lagged 43 & & & & $\begin{array}{r}-0.382 \\
(0.278)\end{array}$ & & & & $\begin{array}{r}-0.410 \\
(0.261)\end{array}$ \\
\hline \multicolumn{9}{|c|}{ Panel D. Dependent variable: Log Deviation of Consumption. District Level (Obs=725) } \\
\hline Tariff Measure & $\begin{array}{r}-0.009 \\
(0.131)\end{array}$ & $\begin{array}{r}-0.037 \\
(0.120)\end{array}$ & $\begin{array}{r}-0.095 \\
(0.098)\end{array}$ & $\begin{array}{r}0.044 \\
(0.108)\end{array}$ & $\begin{array}{r}-0.005 \\
(0.081)\end{array}$ & $\begin{array}{r}-0.004 \\
(0.082)\end{array}$ & $\begin{array}{l}-0.079 \\
(0.074)\end{array}$ & $\begin{array}{r}0.020 \\
(0.097)\end{array}$ \\
\hline Logmean & & $\begin{array}{l}-0.078 * * * \\
(0.018)\end{array}$ & $\begin{array}{l}-0.031 * \\
(0.018)\end{array}$ & & & $\begin{array}{l}-0.077 * * * \\
(0.019)\end{array}$ & $\begin{array}{l}-0.030 \\
(0.019)\end{array}$ & \\
\hline Trend & & & $\begin{array}{l}-0.584 * * * \\
(0.100)\end{array}$ & & & & $\begin{array}{l}-0.584 * * * \\
(0.100)\end{array}$ & \\
\hline Lagged 43 & & & & $\begin{array}{l}-0.570 * \\
(0.309)\end{array}$ & & & & $\begin{array}{c}-0.547 * \\
(0.309)\end{array}$ \\
\hline
\end{tabular}

Note: All regressions include year, district dummies, state labor laws-year dummies and pre-reform literacy, share of SC/ST population and industrial structure interacted with a post dummy. Regressions are weighted by the square root of the number of people in a district/region. The data are from the 43rd and 55th rounds of the NSS. Standard errors (in parentheses) are corrected for clustering at the state year level. Significance at the 10 percent level of confidence is represented by a $*$, at the 5 percent level by $* *$, and at the 1 percent level by $* * *$. In columns (1)-(4), the district tariff is instrumented by the non-scaled tariff. In columns (5)-(8), the district tariff is instrumented by the nonscaled tariff and the interaction of pre-reform non-scaled tariff and a post dummy. In column (4) and (8) the level of the lagged dependent variable is instrumented with the value of the dependent variables in 1983. 


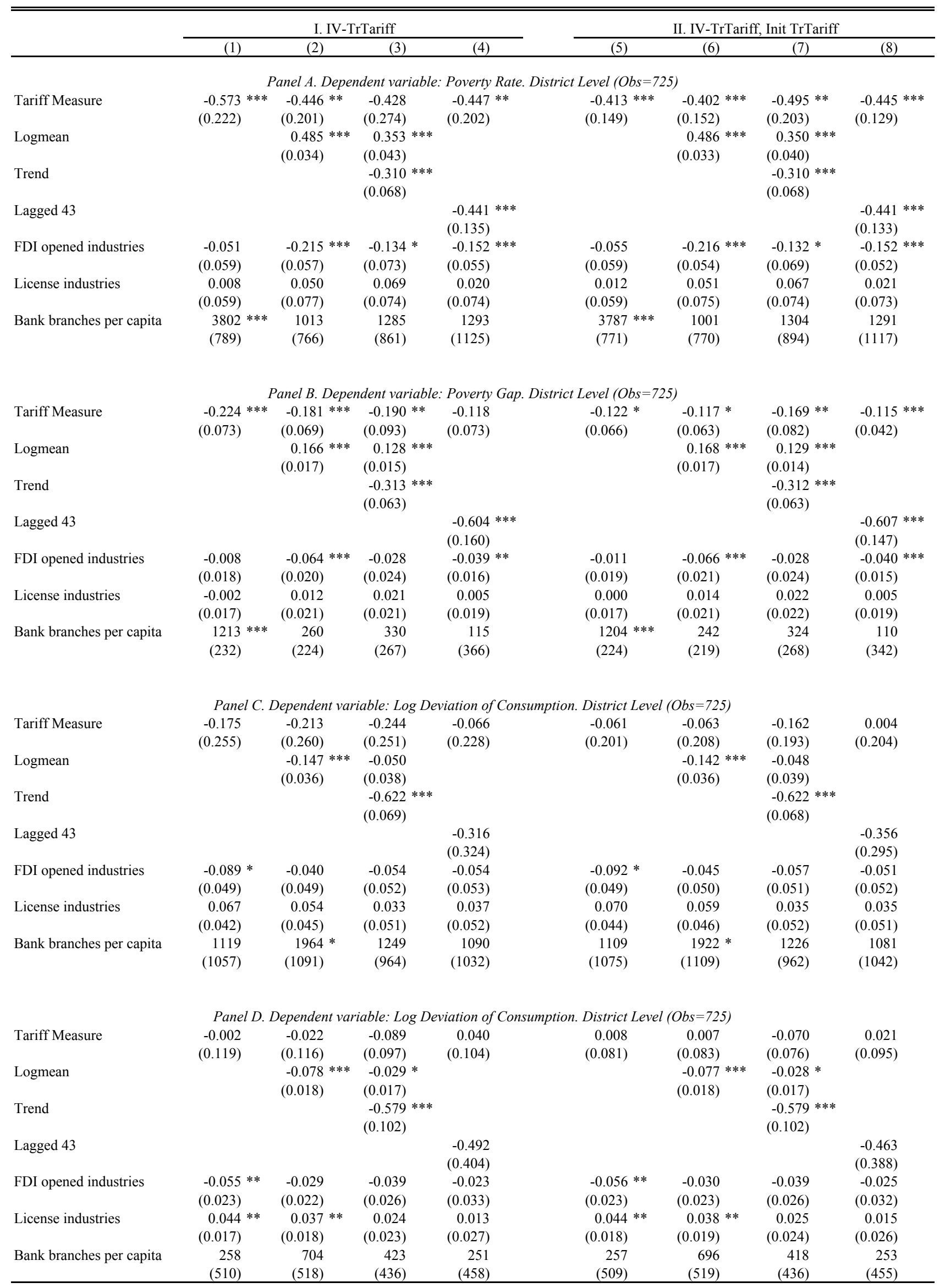

Note: All regressions include year, district dummies, state labor laws-year dummies and pre-reform literacy, share of SC/ST population and industrial structure interacted with a post dummy. Regressions are weighted by the square root of the number of people in a district/region. The data are from the 43rd and 55th rounds of the NSS. Standard errors (in parentheses) are corrected for clustering at the state year level. Significance at the 10 percent level of confidence is represented by a $*$, at the 5 percent level by **, and at the 1 percent level by ***. In columns (1)-(4), the district tariff is instrumented by the non-scaled tariff. In columns (5)-(8), the district tariff is instrumented by the non-scaled tariff and the interaction of pre-reform non-scaled tariff and a post dummy. In column (4) and (8) the level of the lagged dependent variable is instrumented with the value of the dependent variables in 1983. 
Table 7. Migration Patterns

\begin{tabular}{|c|c|c|c|c|c|c|c|c|c|}
\hline & \multicolumn{3}{|c|}{ All } & \multicolumn{3}{|c|}{ Male } & \multicolumn{3}{|c|}{ Female } \\
\hline & 1983 & 1987 & 1999 & 1983 & 1987 & 1999 & 1983 & 1987 & 1999 \\
\hline \multicolumn{10}{|c|}{ Panel A. Rural } \\
\hline Place of Birth Different than Place of Residence & 0.209 & 0.232 & 0.244 & 0.072 & 0.075 & 0.069 & 0.351 & 0.399 & 0.427 \\
\hline Moved within the past 10 years & 0.094 & 0.102 & 0.097 & 0.047 & 0.048 & 0.040 & 0.144 & 0.160 & 0.156 \\
\hline $\begin{array}{l}\text { Moved within the past } 10 \text { years, excluding migration within the same } \\
\text { district and within the same sector (I.e. rural to rural and urban to urban) }\end{array}$ & 0.029 & 0.032 & 0.036 & 0.020 & 0.021 & 0.021 & 0.039 & 0.044 & 0.051 \\
\hline Moved within the past 10 years from urban to rural & 0.011 & 0.013 & 0.013 & 0.010 & 0.011 & 0.011 & 0.012 & 0.015 & 0.016 \\
\hline $\begin{array}{l}\text { Moved within the past } 10 \text { years because of employment, excluding } \\
\text { migration within the same district and within the same sector }\end{array}$ & 0.005 & 0.005 & 0.004 & 0.008 & 0.009 & 0.007 & 0.002 & 0.002 & 0.001 \\
\hline \multicolumn{10}{|c|}{ Panel B. Urban } \\
\hline Place of Birth Different than Place of Residence & 0.316 & 0.329 & 0.333 & 0.270 & 0.268 & 0.256 & 0.366 & 0.396 & 0.418 \\
\hline Moved within the past 10 years & 0.182 & 0.185 & 0.174 & 0.168 & 0.164 & 0.151 & 0.198 & 0.209 & 0.199 \\
\hline $\begin{array}{l}\text { Moved within the past } 10 \text { years, excluding migration within the same } \\
\text { district and within the same sector (I.e. rural to rural and urban to urban) }\end{array}$ & 0.131 & 0.132 & 0.131 & 0.125 & 0.121 & 0.118 & 0.138 & 0.144 & 0.146 \\
\hline Moved within the past 10 years from rural to urban & 0.080 & 0.080 & 0.076 & 0.073 & 0.070 & 0.065 & 0.087 & 0.091 & 0.089 \\
\hline $\begin{array}{l}\text { Moved within the past } 10 \text { years because of employment, excluding } \\
\text { migration within the same district and within the same sector }\end{array}$ & 0.044 & 0.042 & 0.033 & 0.074 & 0.071 & 0.058 & 0.010 & 0.011 & 0.006 \\
\hline
\end{tabular}



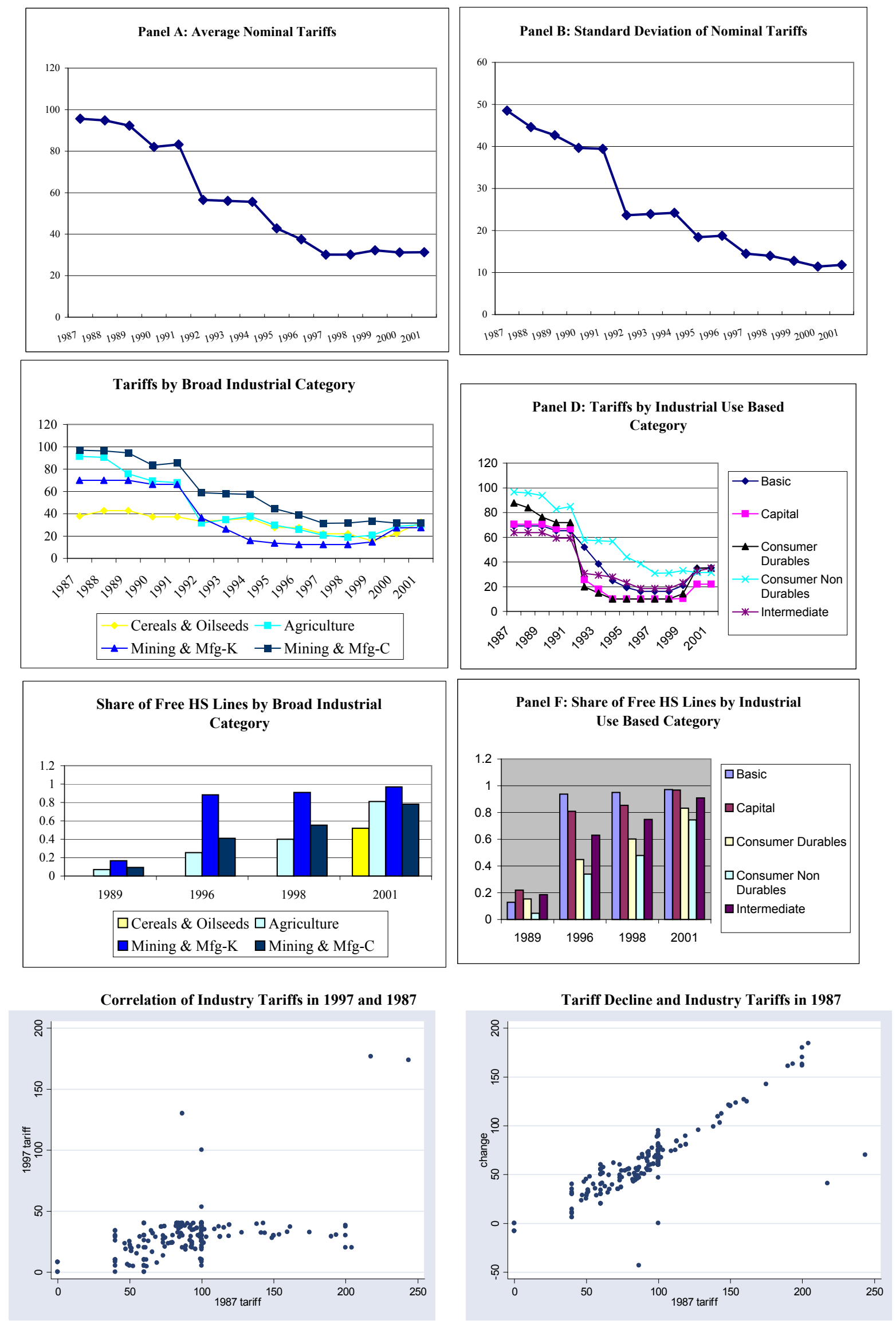
Fig. 2 Evolution of India's Trade
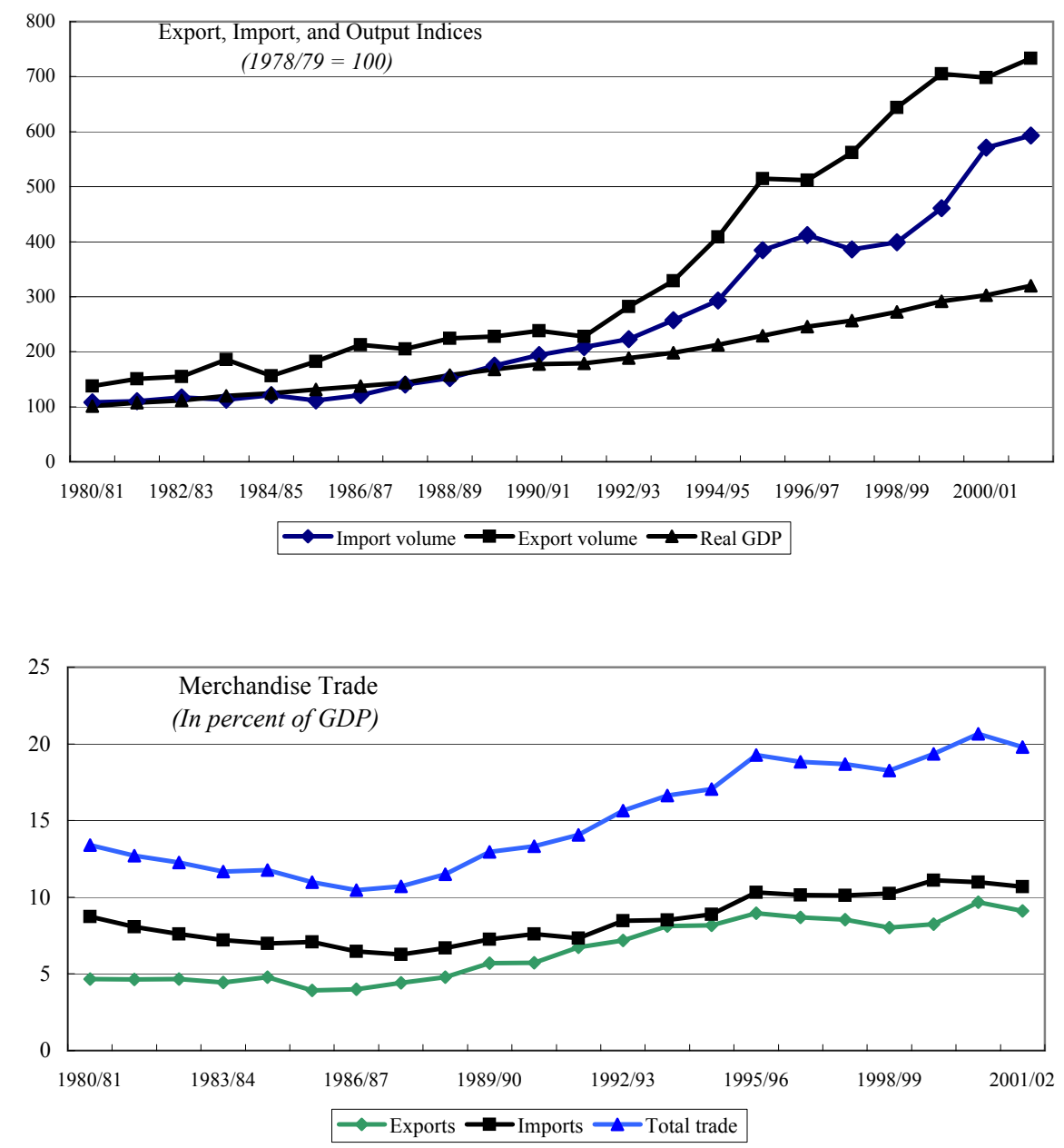

Fig. 3 Pattern of Indian Trade

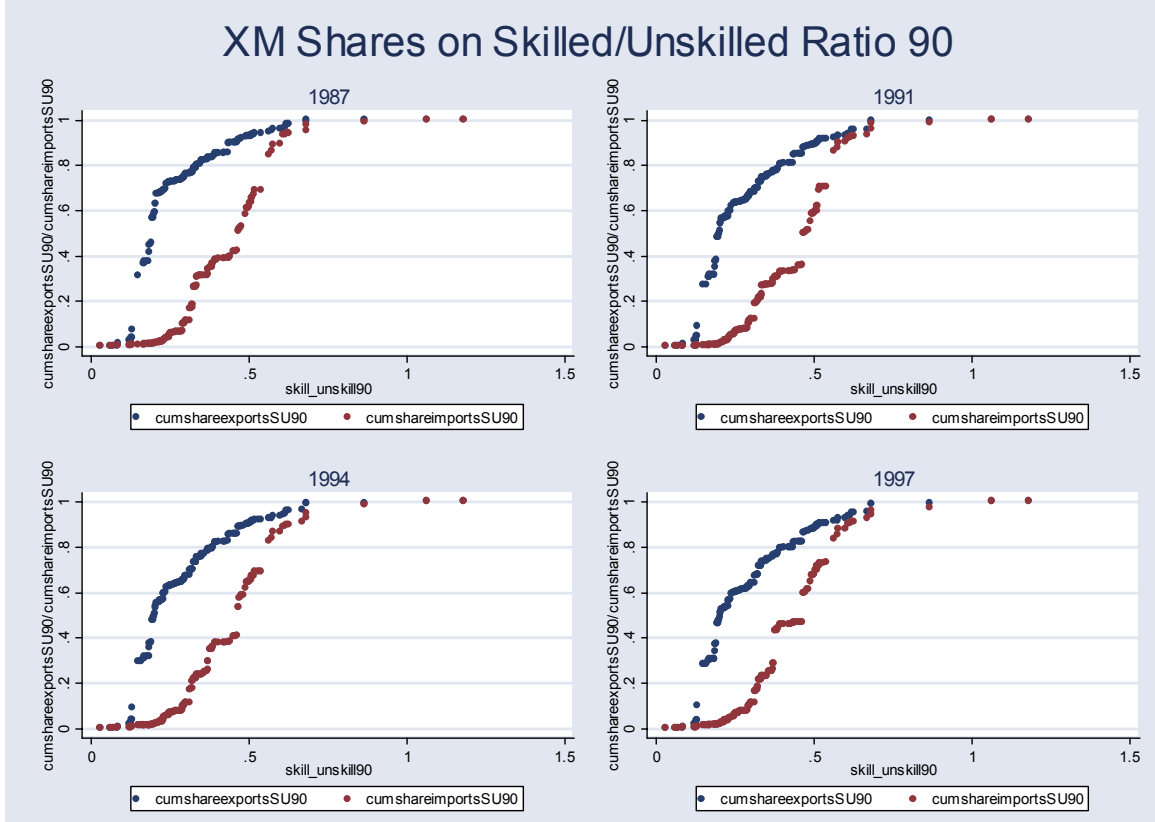




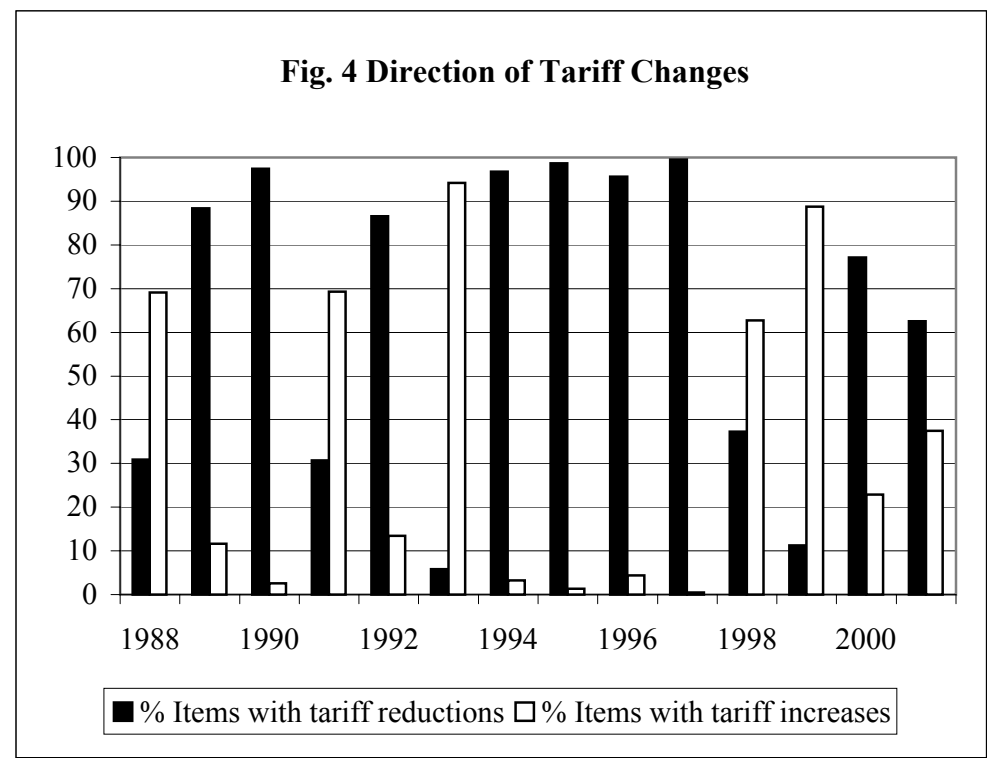

Fig. 5 Trends in Rural and Urban Poverty and Inequality
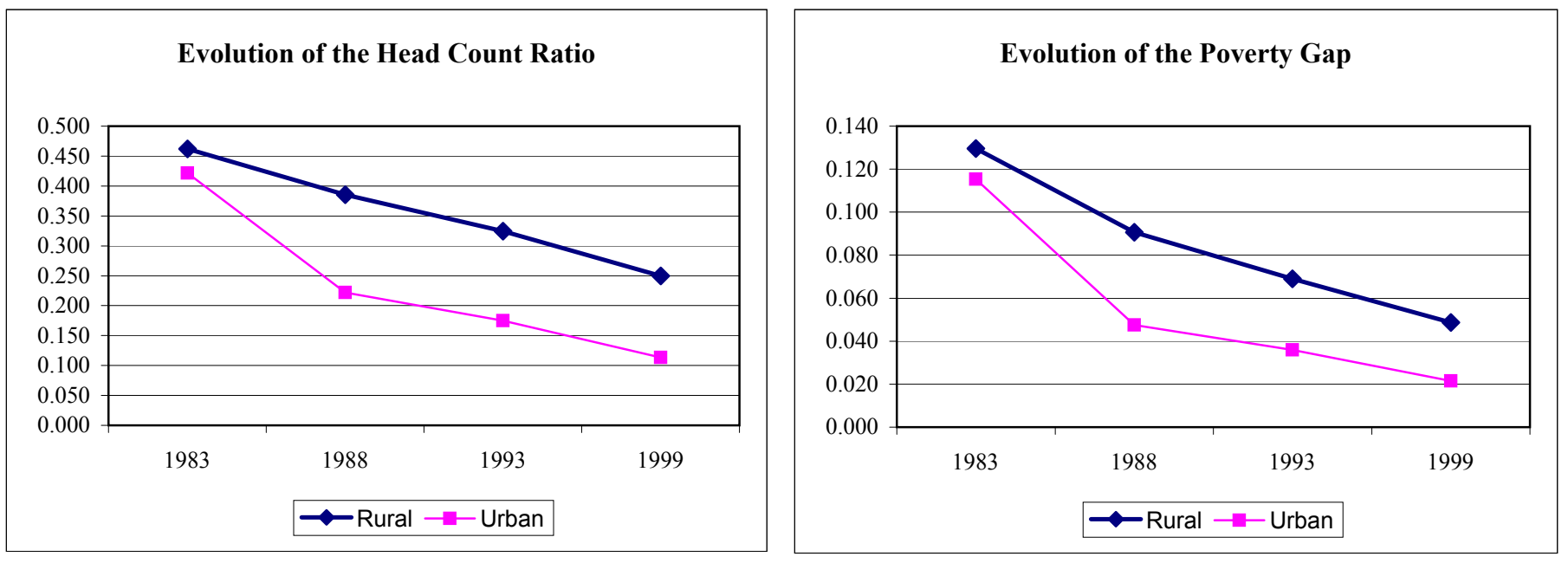

Evolution of the Log Deviation of Consumption

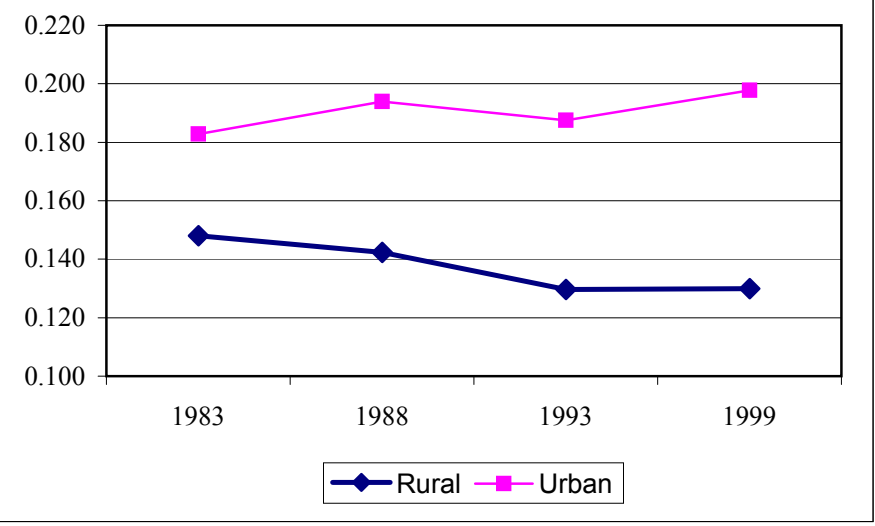

Evolution of the Std Dev of Log Consumption

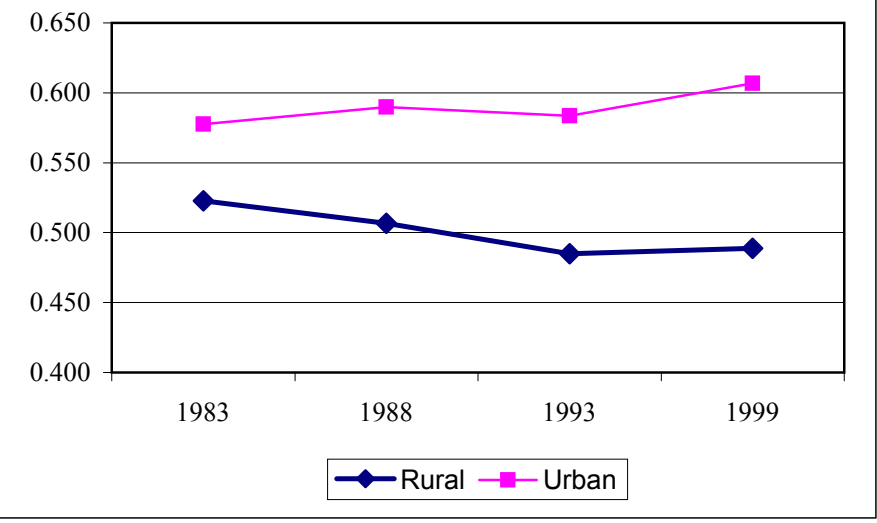


RURAL 38TH ROUND 1983

\begin{tabular}{lccc}
\hline \hline Variable & Obs & Mean & Std. Dev. \\
\hline Poverty Rate & 379 & 0.429 & 0.173 \\
Poverty Gap & 379 & 0.117 & 0.067 \\
Std Dev of Log Consumption & 379 & 0.497 & 0.061 \\
Logarithmic Deviation & 379 & 0.137 & 0.037 \\
Tariff & & - & - \\
TrTariff & & - & - \\
Agricultral Tariff & & - & - \\
Mining and Manufacturing Tariff & & - & - \\
\hline
\end{tabular}

RURAL 43rd ROUND 1987

\begin{tabular}{lccc}
\hline \hline Variable & Obs & Mean & Std. Dev. \\
\hline Poverty Rate & 379 & 0.368 & 0.196 \\
Poverty Gap & 379 & 0.088 & 0.064 \\
Std Dev of Log Consumption & 379 & 0.456 & 0.085 \\
Logarithmic Deviation & 379 & 0.120 & 0.046 \\
Poverty Gap Change in the 1980s & 379 & -0.029 & 0.062 \\
Poverty Rate Change in the 1980s & 379 & -0.061 & 0.164 \\
Std Dev Change in the 1980s & 379 & -0.040 & 0.081 \\
Log Deviation Change in the 1980s & 379 & -0.017 & 0.048 \\
Tariff & 364 & 0.081 & 0.080 \\
TrTariff & 364 & 0.883 & 0.096 \\
Agricultral Tariff & 364 & 0.822 & 0.142 \\
Mining and Manufacturing Tariff & 364 & 0.914 & 0.043 \\
Log Mean Per Capita Expenditure & 379 & 5.065 & 0.252 \\
Percent Literate & 364 & 0.368 & 0.137 \\
Percent SC/ST & 364 & 0.293 & 0.161 \\
Percent Farmers & 364 & 0.816 & 0.103 \\
Percent Manufacturing & 364 & 0.056 & 0.045 \\
Percent Mining & 364 & 0.005 & 0.014 \\
Percent Service & 364 & 0.065 & 0.037 \\
Percent Trade & 364 & 0.032 & 0.020 \\
Percent Transport & 364 & 0.013 & 0.011 \\
\hline
\end{tabular}

RURAL 50th ROUND 1993

\begin{tabular}{lccc}
\hline \hline Variable & Obs & Mean & Std. Dev. \\
\hline Poverty Rate & 366 & 0.313 & 0.179 \\
Poverty Gap & 366 & 0.067 & 0.052 \\
Std Dev of Log Consumption & 366 & 0.428 & 0.088 \\
Logarithmic Deviation & 366 & 0.105 & 0.048 \\
Tariff & 364 & 0.072 & 0.074 \\
TrTariff & 364 & 0.778 & 0.095 \\
Agricultral Tariff & 364 & 0.632 & 0.130 \\
Mining and Manufacturing Tariff & 364 & 0.825 & 0.054 \\
\hline
\end{tabular}

RURAL 55th ROUND 1999

\begin{tabular}{lccc}
\hline \hline Variable & Obs & Mean & Std. Dev. \\
\hline Poverty Rate & 364 & 0.241 & 0.138 \\
Poverty Gap & 364 & 0.048 & 0.035 \\
Std Dev of Log Consumption & 364 & 0.463 & 0.106 \\
Logarithmic Deviation & 364 & 0.116 & 0.042 \\
Tariff & 364 & 0.026 & 0.022 \\
TrTariff & 364 & 0.306 & 0.060 \\
Agricultral Tariff & 364 & 0.236 & 0.076 \\
Mining and Manufacturing Tariff & 364 & 0.341 & 0.022 \\
\hline
\end{tabular}

URBAN 38TH ROUND 1983

\begin{tabular}{lccc}
\hline \hline Variable & Obs & Mean & Std. Dev. \\
\hline Poverty Rate & 372 & 0.439 & 0.147 \\
Poverty Gap & 372 & 0.122 & 0.051 \\
Std Dev of Log Consumption & 372 & 0.540 & 0.065 \\
Logarithmic Deviation & 372 & 0.163 & 0.042 \\
Tariff & & - & - \\
TrTariff & & - & - \\
Agricultral Tariff & & - & - \\
Mining and Manufacturing Tariff & & - & - \\
\hline
\end{tabular}

\section{URBAN 43rd ROUND 1987}

\begin{tabular}{lccc}
\hline \hline Variable & Obs & Mean & Std. Dev. \\
\hline Poverty Rate & 366 & 0.248 & 0.168 \\
Poverty Gap & 366 & 0.057 & 0.050 \\
Std Dev of Log Consumption & 366 & 0.501 & 0.113 \\
Logarithmic Deviation & 366 & 0.149 & 0.076 \\
Poverty Gap Change in the 1980s & 364 & -0.064 & 0.049 \\
Poverty Rate Change in the 1980s & 364 & -0.191 & 0.145 \\
Std Dev Change in the 1980s & 364 & -0.038 & 0.115 \\
Log Deviation Change in the 1980s & 364 & -0.013 & 0.080 \\
Tariff & 362 & 0.172 & 0.085 \\
TrTariff & 362 & 0.891 & 0.083 \\
Agricultral Tariff & 362 & 0.782 & 0.090 \\
Mining and Manufacturing Tariff & 362 & 0.923 & 0.576 \\
Log Mean Per Capita Expenditure & 366 & 5.389 & 0.274 \\
Percent Literate & 362 & 0.591 & 0.094 \\
Percent SC/ST & 362 & 0.154 & 0.064 \\
Percent Farmers & 362 & 0.194 & 0.101 \\
Percent Manufacturing & 362 & 0.191 & 0.088 \\
Percent Mining & 362 & 0.013 & 0.041 \\
Percent Service & 362 & 0.264 & 0.073 \\
Percent Trade & 362 & 0.217 & 0.045 \\
Percent Transport & 362 & 0.073 & 0.025 \\
\hline
\end{tabular}

URBAN 50th ROUND 1993

\begin{tabular}{lccc}
\hline \hline Variable & Obs & Mean & Std. Dev. \\
\hline Poverty Rate & 354 & 0.191 & 0.098 \\
Poverty Gap & 354 & 0.039 & 0.027 \\
Std Dev of Log Consumption & 368 & 0.539 & 0.056 \\
Logarithmic Deviation & 368 & 0.166 & 0.038 \\
Tariff & 362 & 0.156 & 0.079 \\
TrTariff & 362 & 0.812 & 0.082 \\
Agricultral Tariff & 362 & 0.635 & 0.089 \\
Mining and Manufacturing Tariff & 362 & 0.837 & 0.063 \\
\hline
\end{tabular}

URBAN 55th ROUND 1999

\begin{tabular}{lccc}
\hline \hline Variable & Obs & Mean & Std. Dev. \\
\hline Poverty Rate & 360 & 0.145 & 0.108 \\
Poverty Gap & 360 & 0.029 & 0.027 \\
Std Dev of Log Consumption & 360 & 0.529 & 0.091 \\
Logarithmic Deviation & 360 & 0.157 & 0.054 \\
Tariff & 362 & 0.060 & 0.030 \\
TrTariff & 362 & 0.317 & 0.044 \\
Agricultral Tariff & 362 & 0.212 & 0.052 \\
Mining and Manufacturing Tariff & 362 & 0.336 & 0.030 \\
\hline
\end{tabular}


Table A2. Sectoral Tariffs and Poverty and Inequality in Rural and Urban India

\begin{tabular}{|c|c|c|c|c|c|c|}
\hline & \multicolumn{3}{|c|}{ I. RURAL } & \multicolumn{3}{|c|}{ II. URBAN } \\
\hline & $(1)$ & $(2)$ & (3) & (4) & $(5)$ & $(6)$ \\
\hline \multicolumn{7}{|c|}{ Panel A. Dependent Variable: Poverty Rate } \\
\hline Agricultural Tariff & $\begin{array}{l}-0.219^{* * * *} \\
(0.071)\end{array}$ & & $\begin{array}{l}-0.213 * * * \\
(0.070)\end{array}$ & $\begin{array}{l}-0.242 * * \\
(0.097)\end{array}$ & & $\begin{array}{l}-0.240 * * \\
(0.102)\end{array}$ \\
\hline Mining and Manufacturing Tariff & & $\begin{array}{r}0.277 \\
(0.318)\end{array}$ & $\begin{array}{r}0.221 \\
(0.297)\end{array}$ & & $\begin{array}{r}-0.154 \\
(0.163)\end{array}$ & $\begin{array}{r}-0.148 \\
(0.154)\end{array}$ \\
\hline Obs & 725 & 725 & 725 & 703 & 703 & 703 \\
\hline \multicolumn{7}{|c|}{ Panel B. Dependent variable: Poverty Gap } \\
\hline Agricultural Tariff & $\begin{array}{l}-0.081 * * * \\
(0.021)\end{array}$ & & $\begin{array}{l}-0.080 * * * \\
(0.020)\end{array}$ & $\begin{array}{l}-0.066 * * \\
(0.027)\end{array}$ & & $\begin{array}{l}-0.065 * * \\
(0.029)\end{array}$ \\
\hline Mining and Manufacturing Tariff & & $\begin{array}{r}0.062 \\
(0.123)\end{array}$ & $\begin{array}{r}0.041 \\
(0.113)\end{array}$ & & $\begin{array}{r}-0.072 \\
(0.049)\end{array}$ & $\begin{array}{r}-0.071 \\
(0.047)\end{array}$ \\
\hline Obs & 725 & 725 & 725 & 703 & 703 & 703 \\
\hline \multicolumn{7}{|c|}{ Panel C. Dependent variable: StdLog Consumption } \\
\hline Agricultural Tariff & $\begin{array}{l}-0.110 * \\
(0.064)\end{array}$ & & $\begin{array}{l}-0.110 * \\
(0.062)\end{array}$ & $\begin{array}{r}0.060 \\
(0.091)\end{array}$ & & $\begin{array}{r}0.060 \\
(0.092)\end{array}$ \\
\hline Mining and Manufacturing Tariff & & $\begin{array}{r}0.030 \\
(0.220)\end{array}$ & $\begin{array}{r}0.002 \\
(0.208)\end{array}$ & & $\begin{array}{r}0.000 \\
(0.131)\end{array}$ & $\begin{array}{r}-0.001 \\
(0.129)\end{array}$ \\
\hline Obs & 725 & 725 & 725 & 703 & 703 & 703 \\
\hline \multicolumn{7}{|c|}{ Panel D. Dependent variable: Log Deviation of Consumption } \\
\hline Agricultural Tariff & $\begin{array}{r}-0.037 \\
(0.025)\end{array}$ & & $\begin{array}{l}-0.035 \\
(0.025)\end{array}$ & $\begin{array}{r}0.053 \\
(0.066)\end{array}$ & & $\begin{array}{r}0.053 \\
(0.066)\end{array}$ \\
\hline Mining and Manufacturing Tariff & & $\begin{array}{r}0.073 \\
(0.109)\end{array}$ & $\begin{array}{r}0.064 \\
(0.111)\end{array}$ & & $\begin{array}{r}0.024 \\
(0.076)\end{array}$ & $\begin{array}{r}0.022 \\
(0.074)\end{array}$ \\
\hline Obs & 725 & 725 & 725 & 703 & 703 & 703 \\
\hline
\end{tabular}

Note: All regressions include year and district dummies. Standard errors (in parentheses) are corrected for clustering at the state year level. Regressions are weighted by the square root of the number of people in a district. Significance at the 10 percent level of confidence is represented by a *, at the 5 percent level by **, and at the 1 percent level by ***. 
Table A3. Imports, Export and Poverty in Rural India

\begin{tabular}{|c|c|c|c|c|c|c|c|c|}
\hline DepVar: Poverty Rate & $(1)$ & $(2)$ & (3) & $(4)$ & $(5)$ & $(6)$ & $(7)$ & $(8)$ \\
\hline Imports of All Traded Industries & $\begin{array}{r}0.010 \\
(0.006)\end{array}$ & & & & $\begin{array}{l}0.009 * \\
(0.005)\end{array}$ & & & \\
\hline Imports of Agriculture & & $\begin{array}{r}0.009 \\
(0.012)\end{array}$ & & $\begin{array}{r}0.007 \\
(0.013)\end{array}$ & & $\begin{array}{l}0.017 * \\
(0.009)\end{array}$ & & $\begin{array}{l}0.016 \text { * } \\
(0.009)\end{array}$ \\
\hline Imports of Mining/Manufacture & & & $\begin{array}{l}0.008 * * * \\
(0.003)\end{array}$ & $\begin{array}{l}0.009 * * * \\
(0.003)\end{array}$ & & & $\begin{array}{r}0.006 \\
(0.004)\end{array}$ & $\begin{array}{r}0.006 \\
(0.004)\end{array}$ \\
\hline Exports of All Traded Industries & $\begin{array}{l}-0.002 * \\
(0.001)\end{array}$ & & & & $\begin{array}{r}-0.002 \\
(0.001)\end{array}$ & & & \\
\hline Exports of Agriculture & & $\begin{array}{r}-0.0003 \\
(0.0018)\end{array}$ & & $\begin{array}{l}-0.001 \\
(0.002)\end{array}$ & & $\begin{array}{r}-0.001 \\
(0.001)\end{array}$ & & $\begin{array}{r}-0.001 \\
(0.001)\end{array}$ \\
\hline Exports of Mining/Manufacture & & & $\begin{array}{l}-0.002 * * \\
(0.001)\end{array}$ & $\begin{array}{l}-0.002 * * \\
(0.001)\end{array}$ & & & $\begin{array}{l}-0.002 * \\
(0.001)\end{array}$ & $\begin{array}{l}-0.001 * \\
(0.001)\end{array}$ \\
\hline FDI opened industries & $\begin{array}{l}-0.215 * * * \\
(0.060)\end{array}$ & $\begin{array}{l}-0.230 \text { *** } \\
(0.061)\end{array}$ & $\begin{array}{l}-0.247 \text { *** } \\
(0.055)\end{array}$ & $\begin{array}{l}-0.251 * * * \\
(0.057)\end{array}$ & $\begin{array}{l}-0.164 * * * \\
(0.056)\end{array}$ & $\begin{array}{l}-0.169 * * * \\
(0.054)\end{array}$ & $\begin{array}{l}-0.187 \text { *** } \\
(0.051)\end{array}$ & $\begin{array}{l}-0.188 * * * \\
(0.048)\end{array}$ \\
\hline License industries & $\begin{array}{r}0.048 \\
(0.070)\end{array}$ & $\begin{array}{r}0.064 \\
(0.076)\end{array}$ & $\begin{array}{r}0.056 \\
(0.072)\end{array}$ & $\begin{array}{r}0.055 \\
(0.072)\end{array}$ & $\begin{array}{r}0.020 \\
(0.065)\end{array}$ & $\begin{array}{r}0.034 \\
(0.071)\end{array}$ & $\begin{array}{r}0.031 \\
(0.070)\end{array}$ & $\begin{array}{r}0.029 \\
(0.069)\end{array}$ \\
\hline Bank branches per capita & $\begin{array}{r}872 \\
(685)\end{array}$ & $\begin{array}{r}863 \\
(727)\end{array}$ & $\begin{array}{r}963 \\
(710)\end{array}$ & $\begin{array}{r}957 \\
(697)\end{array}$ & $\begin{array}{r}861 \\
(1013)\end{array}$ & $\begin{array}{r}1059 \\
(1099)\end{array}$ & $\begin{array}{r}941 \\
(1115)\end{array}$ & $\begin{array}{r}981 \\
(1101)\end{array}$ \\
\hline Logmean & $\begin{array}{l}0.504 \text { *** } \\
(0.035)\end{array}$ & $\begin{array}{l}0.500 \text { *** } \\
(0.033)\end{array}$ & $\begin{array}{l}0.503 \text { *** } \\
(0.033)\end{array}$ & $\begin{array}{l}0.502 \text { *** } \\
(0.033)\end{array}$ & & & & \\
\hline Lagged 43 & & & & & $\begin{array}{l}-0.511 * * * \\
(0.128)\end{array}$ & $\begin{array}{l}-0.468 * * * \\
(0.142)\end{array}$ & $\begin{array}{l}-0.508 * * * \\
(0.137)\end{array}$ & $\begin{array}{l}-0.495 * * * \\
(0.142)\end{array}$ \\
\hline Obs & 725 & 725 & 725 & 725 & 725 & 725 & 725 & 725 \\
\hline
\end{tabular}

Note: All regressions include year, district dummies, state labor laws-year dummies and pre-reform literacy, share of SC/ST population and industrial structure interacted with a post dummy. Regressions are weighted by the square root of the number of people in a district/region. The data are from the 43rd and 55th rounds of the NSS. Standard errors (in parentheses) are corrected for clustering at the state year level. Significance at the 10 percent level of confidence is represented by a $*$, at the 5 percent level by $* *$, and at the 1 percent level by ***. In columns (1)-(4), the district initial per capita expenditure interacted with a post dummy is included. In columns (5)-(8), the level of the lagged dependent variable, instrumented with the value of the dependent variables in 1983, and interacted with a post dummy is included. 